\title{
Percorsi cerimoniali e organizzazione distributiva nei palazzi barocchi torinesi. Palazzo Capris di Ciglié
}

\author{
Marco Vitali \\ Concepción López González \\ Giulia Bertola \\ Fabrizio Natta
}

Abstract

A partire dai ragionamenti che legano gli spazi a uso promiscuo (pubblico-privato) dei palazzi nobiliari alla qualità e al decoro della scena urbana, si prova in questa sede, sulla scorta delle ricerche svolte in precedenza sui sistemi voltati complessi, a individuare nel repertorio di edifici barocchi censiti e rilevati all'interno del tessuto storico della città di Torino alcuni schemi organizzativi ricorrenti a testimonianza delle principali linee di sviluppo e trasformazione degli archetipi di progetto in aderenza al gusto estetico formale e al mutare delle esigenze funzionali. In questo senso, gli spazi del palazzo dedicati al cerimoniale di ingresso e ricevimento compartecipano alla definizione di un nucleo progettuale fondamentale, generalmente risolto con grande impegno compositivo e scenografico unitario, assumendo una chiara individualità nella struttura del palazzo. Su uno degli edifici presi in considerazione per la schematizzazione grafica, Palazzo Capris di Cigliè, si testa una metodologia di rilevamento laser scanner e restituzione finalizzata all'implementazione degli schemi nelle fasi successive della ricerca.

Parole chiave

cerimoniale di ingresso, architettura barocca, rilievo laser scanner, rappresentazione.
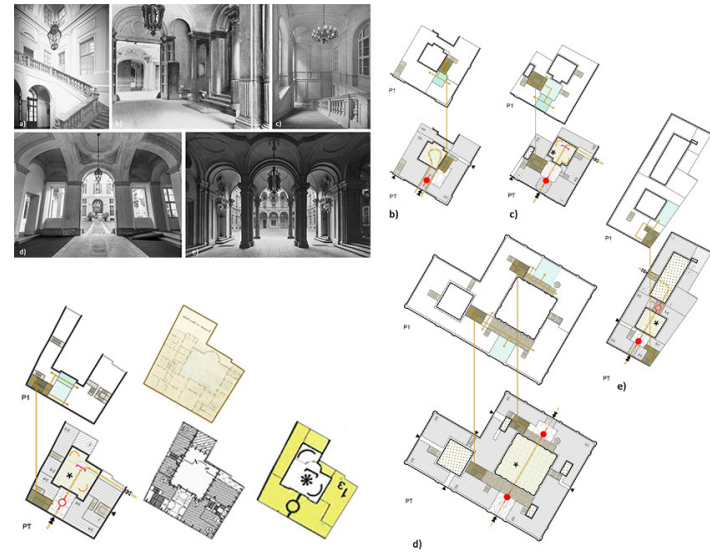

1274

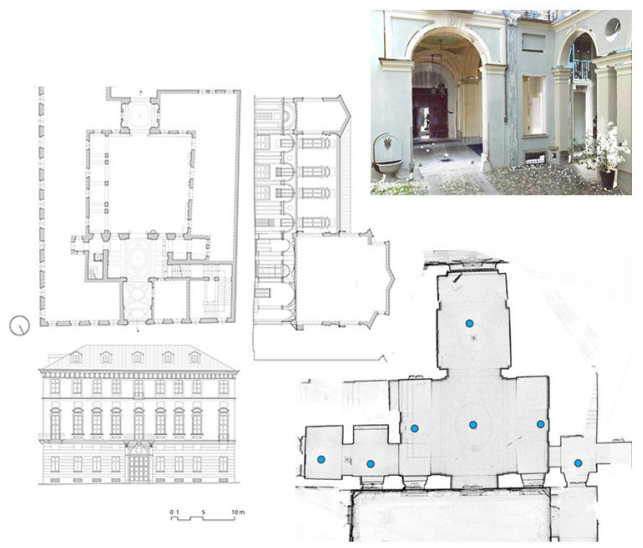

doi.org/ | 0.3280/oa-693.72 


\section{Introduzione}

II presente studio affonda le proprie radici nella più ampia ricerca che, ormai da una decina d'anni, si sta conducendo sui sistemi voltati complessi [I] e che ha visto il gruppo di ricerca impegnato nell'analisi e nello studio del rapporto tra geometria, forma e progetto nella composizione e realizzazione degli atri di palazzi nobiliari all'interno del tessuto storico della città di Torino in epoca barocca [Spallone,Vitali 20 17]. A partire dai ragionamenti che legano gli spazi a uso promiscuo (pubblico-privato) dei palazzi nobiliari alla qualità e al decoro della scena urbana - così come testimoniato da tanta parte della produzione cartografica del periodo Barocco, sia a livello nazionale [2] che a livello locale - si prova in questa sede, anche sulla scorta dei precedenti studi condotti in questo senso [Politecnico di Torino 1968, pp. 616-667], a individuare, nel repertorio di edifici censiti e rilevati, alcuni schemi organizzativi ricorrenti a testimonianza delle principali linee di sviluppo e trasformazione degli archetipi di progetto in aderenza al gusto estetico formale e al mutare delle esigenze funzionali.

In questo senso, gli spazi del palazzo dedicati al cerimoniale di ingresso e ricevimento (atrio e spazi accessori e di connessione con la corte d'onore, come anditi, gallerie, ecc., l'eventuale corte rustica, lo scalone, e il salone e i locali a esso connessi al piano nobile) compartecipano alla definizione di un nucleo progettuale fondamentale, generalmente risolto con grande impegno compositivo e scenografico unitario, assumendo una chiara individualità nella struttura del palazzo (fig. I).

Fig. I. Il percorso cerimoniale del palazzo barocco torinese raccontato attraverso le immagini: a) scalone del palazzo Vallesa della Martinian b) atrio del palazzo Mazzonis; c) scalone del palazzo Valperga Gallenai di Barbaresco; d) atrio del palazzo Capris di
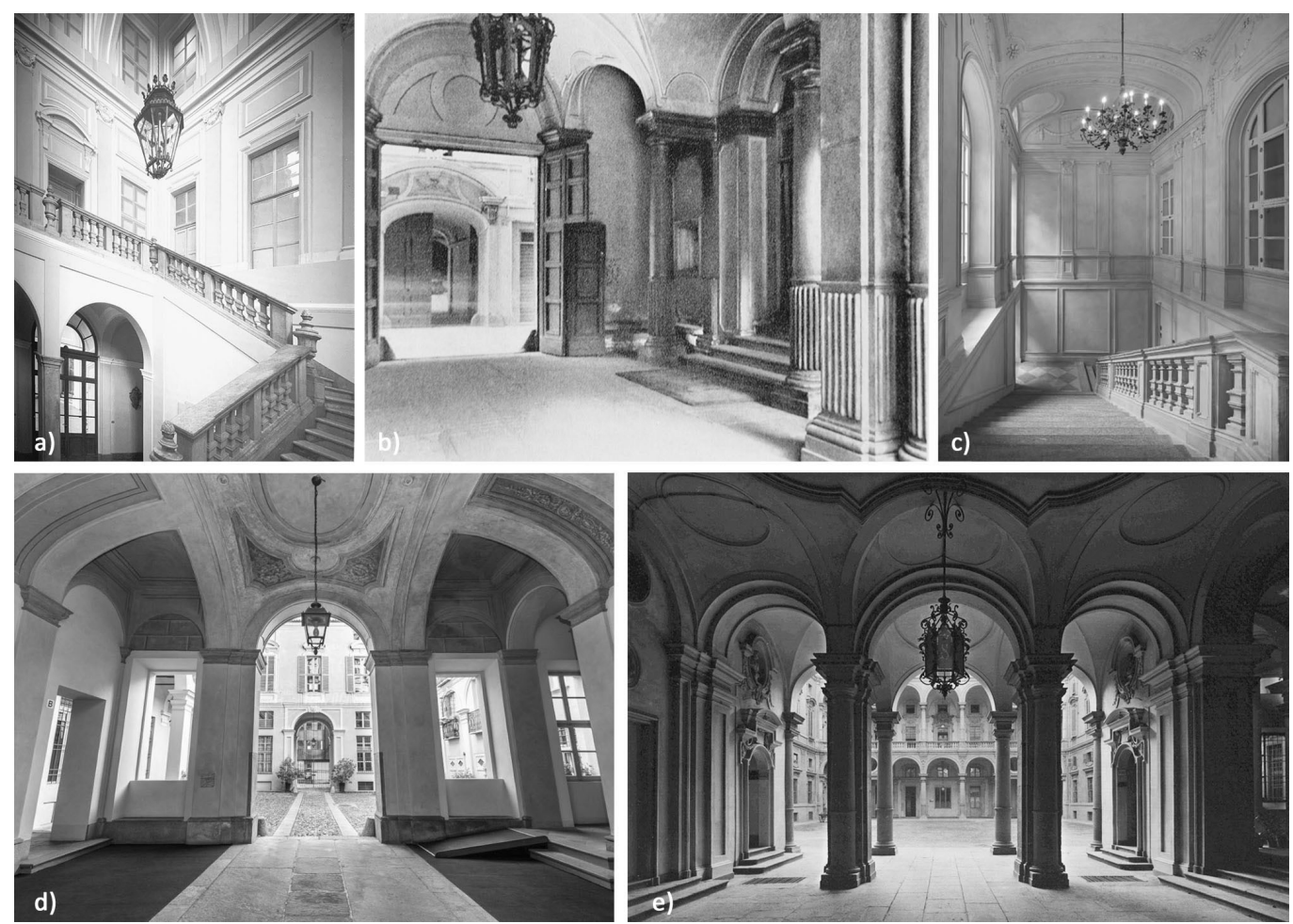

\section{Esigenze del percorso cerimoniale e organizzazione distributiva}

Gli edifici nobiliari barocchi del tessuto storico della città di Torino testimoniano atteggiamenti compositivi che da un lato raccolgono le istanze legate al recupero e al restauro di vecchi palazzi, solitamente risolto con spese di modesta entità e con soluzioni compositive di scarsa rilevanza, dall'altra affrontano la riconfigurazione degli spazi interni, e in particolare del nucleo centrale adibito al cerimoniale di ingresso e rivevimento, proponendo soluzioni progettuali originali. Esse definiscono spazi unitari, ma distinti, che attraverso il meccanismo 
Fig. 2. Luigi Michele Barberis, progetto della facciata del palazzo Galleani Canelli di Barbaresco, II aprile I78I, (A.S.T., Corte). L'impaginazione di facciata evidenzia come mezzanini partecipino all'organizzazione funzionale dei singoli piani.

Fig. 3. Palazzo Vallesa della Martiniana. Taglio in lungo dell'atrio del palazzo Lui Michele Barberis 1783. Michele Barberis, 1783 . I disegni sono conservat Provan di Unberto Provana di Collegno Cumiana. della compenetrazione spaziale compongono sistemi ad alto tenore rappresentativo, caratterizzati da soluzioni distributive e funzionali diversificate e attillate al mutare delle esigenze del cerimoniale. La individuazione di tali archetipi e la loro schematizzazione passa attraverso un'analisi che prende in considerazione molteplici aspetti della costruzione:

I. gli schemi di pianta riferiti all'edificio (al piano terra e al piano nobile), in parte desunti dalla cartografia di riferimento [Magnaghi 1992], in parte da documenti archivistici di progetto, di rilievo e descrizioni di carattere storico;

2. la composizione dei prospetti, che denucia attraverso la presenza e organizzazione dei piani mezzanini l'armonizzazione di spazi adibiti al cerimoniale (alcuni dei quali a doppia altezza, come testimoniano disegni e sezioni di progetto) e spazi deidicati al servizio (figg. 2, 3), connessi a essi attraverso scale secondarie e percorsi defilati;

3. gli schemi che connettono l'organizzazione del palazzo con la struttura dell'isolato e la distribuzione di ingressi e corti (d'onore e rustiche), definiti dalle mappe filologico-congetturali [Politecnico di Torino 1968, II, A] e dalle tavole relative a contesti di interesse culturale e ambientale [Città di Torino 1994,Tav. 2].
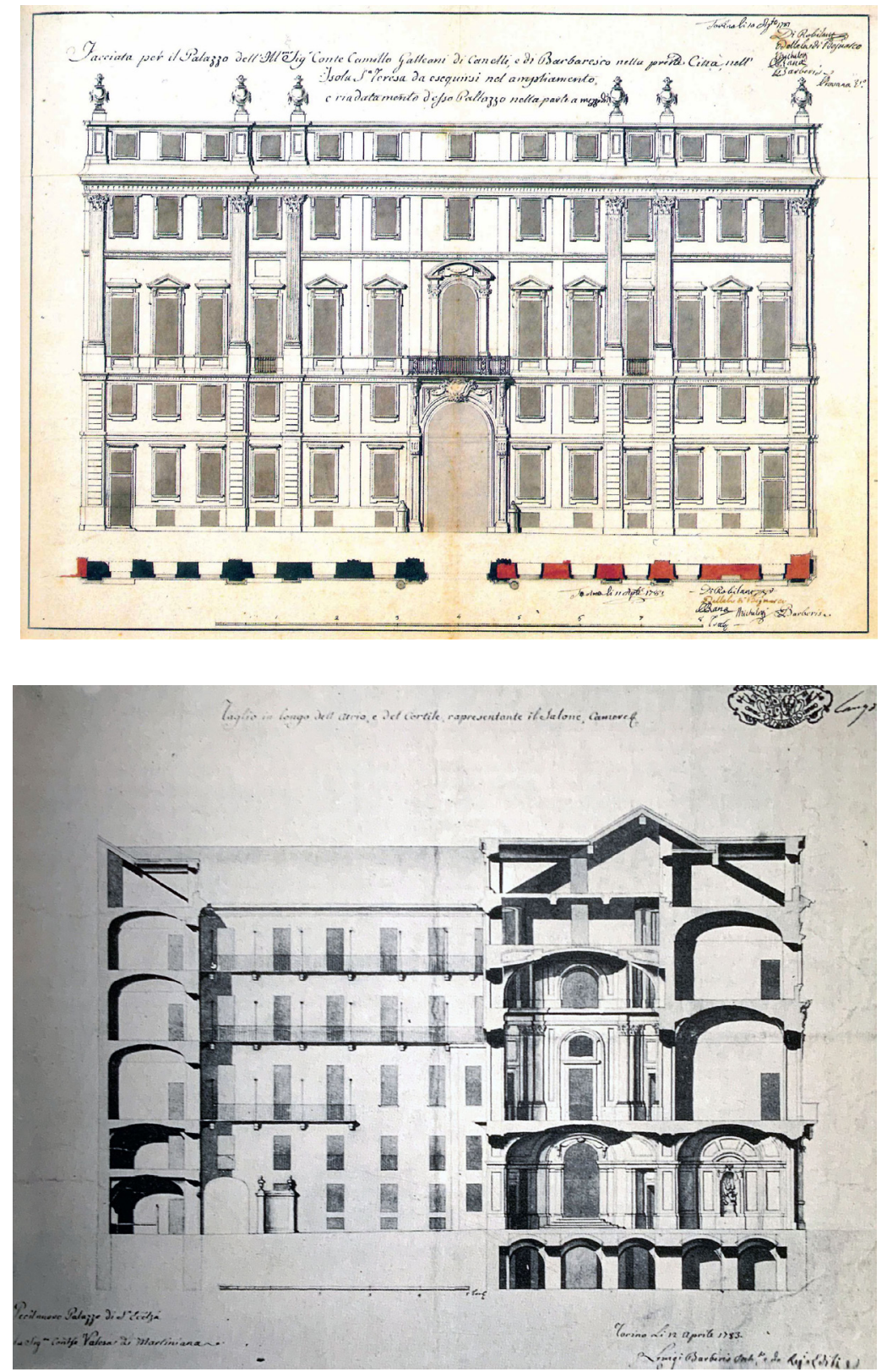
Fig. 4. Schema distributivo relativo a Palazzo

Mazzonis: dal basso, lo schema prende a prestito, per la definizione degli spazi al piano terra: le informazioni relative alle mappe filologicocongetturali relative ai tessuti urbani nell'ultimo quarto del Settecento [Politecnico di Torin 1968, II, A, mappa 2] alle mappe denominate "Contesti urbani di "Contesti urbani di [Città di Torino 1994, 2] per la defizione de ], per la definione degl spazi al piano superiore dell'edificio, eseguite dell'edificio, eseguite nel 1845 [Archivio Storico del Comune d Torino, Tipi e dis., cart. 63, fasc. 9, dis. I, tav. III] (elaborazione grafica Giulia Bertola).
Gli edifici che sono stati selezionati per la redazione degli schemi oggetto del presente studio rappresentano palazzi con caratteristiche omogenee, che vedono alternarsi, su corpi di fabbrica a manica doppia, vetibolo su strada (o andito, nei casi di minor pregio architettonico [3]) e atrio sul cortile [4] (con, in generale, conseguente posizione del salone) o viceversa [5], o ancora schemi di maggiore complessità nei quali ai precedenti elementi si aggiungono gallerie sul cortile che distribuiscono lo scalone al piano terra e disimpegnano il salone al piano superiore [6], elementi scenografici di fondale per la corte d'onore, collegamenti con corti rustiche e accessi carrai secondari.

In ultimo, a testimonianza di edifici che sfuggono, per così dire, a una rigida catalogazione tipologica, è stato studiato lo schema distributivo del palazzo Valperga Galleani di Canelli e Barbaresco, che presenta, probabilmente in virtù delle complesse vicende di ampliamento e ristrutturazione effettuate nella seconda metà del Settecento, una soluzione assolutamente originale, in cui l'atrio, soprelevato rispetto all'androne carraio e completamente vetrato si trasforma in un vero e proprio salone al piano terra, che comunica con una anticamera al piano superiore attraverso uno scalone.
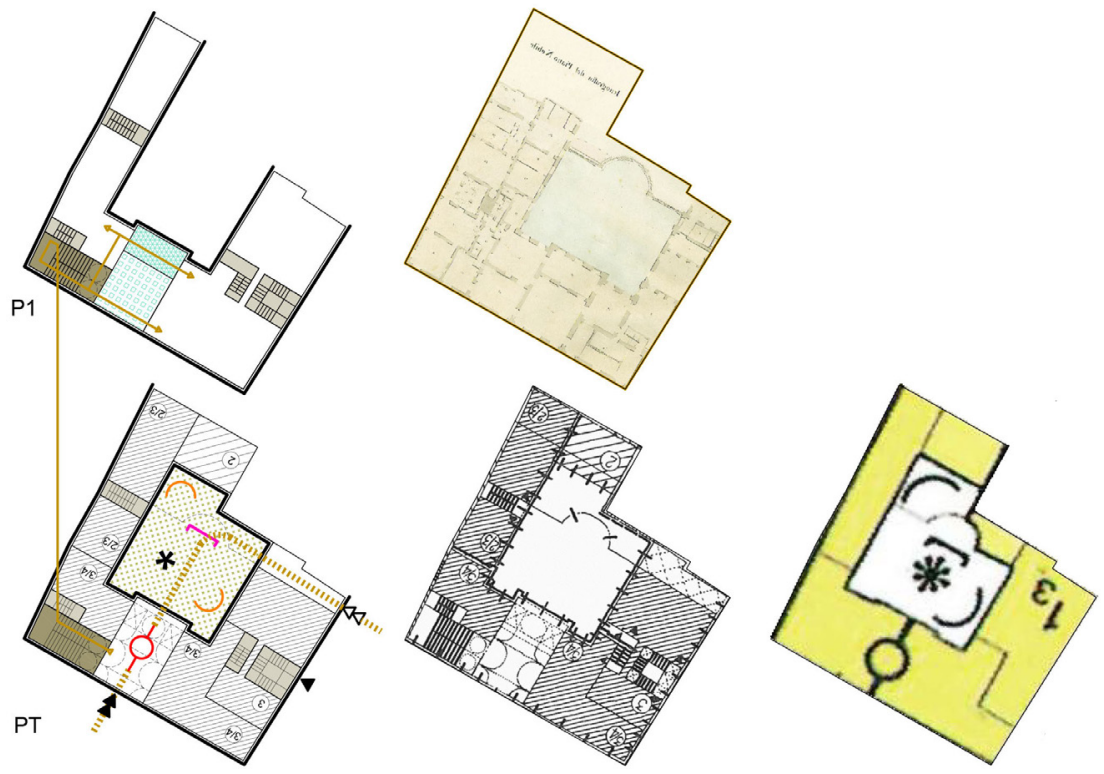

Tipologia e schematizzazione grafica

La realizzazione e la messa a confronto di schemi distributivi e concettuali atti a descrivere percorsi e spazi cerimoniali è stata testata su cinque palazzi nobiliari torinesi edificati tra la fine del secolo XVII e i primi decenni del secolo XVIII: palazzo Saluzzo Paesana [Griseri 1995], palazzo Capris di Cigliè, palazzo Mazz

onis, palazzo Vallesa di Martiniana [Cifani, Monetti 1989a], palazzo Valperga Galleani di Barbaresco [Cifani, Monetti 1989b].

Le elaborazioni grafiche sono state concepite a partire dal confronto e dalla sovrapposizione delle mappe e della cartografia relative alla distribuzione e organizzazione dei piani terra presentate nel precedente paragrafo (fig. 4), che ha garantito una base omogenea e comune ai cinque edifici, completa di informazioni distributive, stereometriche, scenografiche, di legamento architettonico, ecc. In aggiunta sono seguiti approfondimenti finalizzati alla comprensione dell'organizzazione degli spazi al piano nobile, che si sono basati su rilievi storici, disegni d'archivio, descrizioni di carattere storico (fig. 5).

Per la sistemazione dei risultati è stato adottato un criterio diacronico, volto alla messa in valore dei legami tra gli spazi pubblici di vie e piazze e gli spazi privati di atrio ed elementi di distribuzione al piano terra (rappresentati attraverso la proiezione a terra dei sistemi voltati 
che li caratterizzano), il cortile/i cortili e lo scalone. In tal modo si è cercato di sottolineare il carattere di eterogeneità degli spazi all'interno delle diverse cellule edilizie focalizzando l'attenzione sulla varietà del disegno delle connessioni tra gli spazi in ragione dei diversi flussi di persone, animali, cose.

Durante il processo di ri-disegno è stato necessario avvalersi di precisi simboli stereometrici, alcuni ripresi dalle mappe esistenti, altri di nuova creazione. A questi sono stati aggiunti simboli distributivi, volti a indicare flussi all'interno degli spazi di circolazione orizzontale (androni, vestiboli, anditi, corridoi, gallerie), gli spazi di circolazione verticale d'onore e di servizio (scale e rampe), gli spazi privati di residenza (salone, accessi agli appartamenti) (fig. 6). Per quanto riguarda gli accessi e i percorsi sono stati indicati gli ingressi principali distinti rispetto a quelli di servizio e gli accessi agli alloggi del palazzo differenziando i percorsi pedonali da quelli delle carrozze.

A questi simboli sono stati in seguito sovrapposti alcuni derivanti dagli Ideogrammi della monumentalità [Politecnico di Torino 1968, Vol. I, II; B, I] e recuperati nelle tavole pubblicate nel 1994 in occasione del progetto del nuovo piano regolatore di Torino. Tali elementi descrivono i caratteri peculiari di spazi come quelli di collegamento tra la via e il cortile (anditi, androni), spazi di cortile risolti architettonicamente e rispondenti a intenzioni di prestigio, spesso arricchiti dalla presenza di fondali, e gli spazi di cortile appartenenti a cellule diverse di uno stesso isolato.

Fig. 5. Schemi descrittivi del cerimoniale di ingresso e ricevimento relativi b) Valperga Galleani di Barbaresco; c) Vallesa della Martirana; d) Saluzzo Paesana: e) Caris di Ciglie (elaborazione (elaborazione grafic

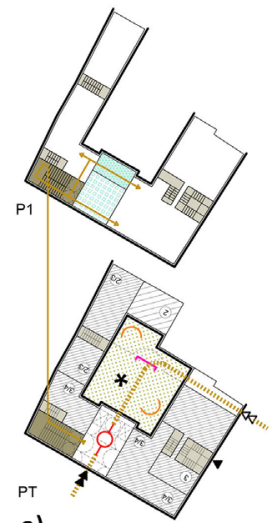

a)

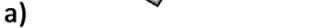

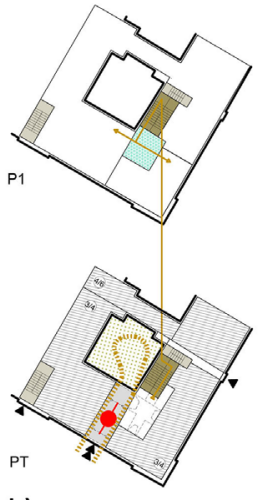

b)

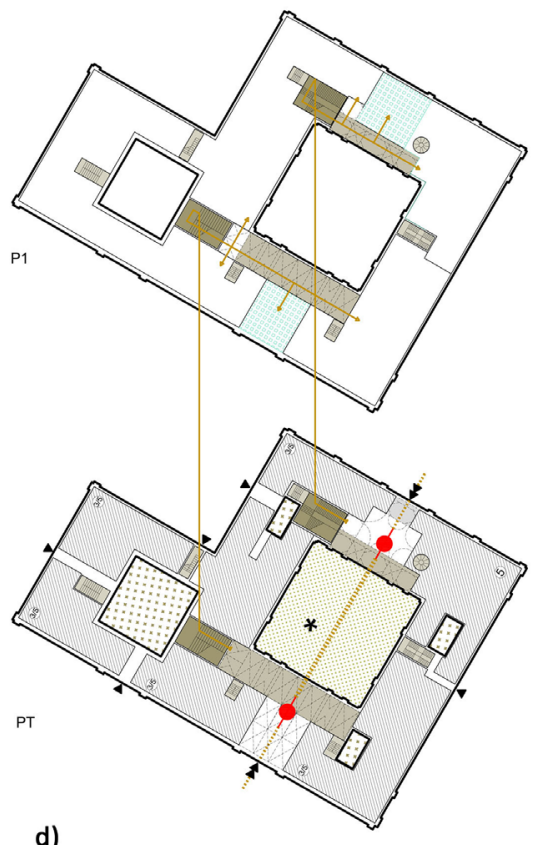

d)

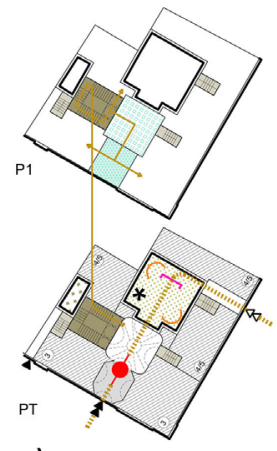

c)

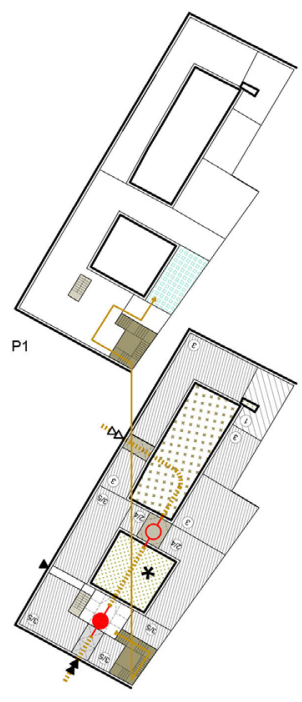

e) 
Fig. 6. Legenda relativa agli schemi descrittivi de percorso cerimoniale di ingresso e ricevimento nei palazzı barocchi Torino (elaborazione grafica Giulia Bertola).

\begin{tabular}{|c|c|c|c|}
\hline & $\begin{array}{l}\text { Percorsi passanti al cortile sviluppati a doppia } \\
\text { altezza }\end{array}$ & & Distribuzione verticale \\
\hline & $\begin{array}{l}\text { Percorsi passanti al cortile sviluppati a } \\
\text { semplice altezza }\end{array}$ & " & Percorsi cerimoniali delle carrozze \\
\hline & Fondale di composizione architettonica chiusa & & $\begin{array}{l}\text { Volume edilizio alto delimitato da facciata con } \\
\text { coronamento }\end{array}$ \\
\hline & $\begin{array}{l}\text { Legami tra spazi di cortile appartenenti } \\
\text { a cellule diverse di uno stesso spazio }\end{array}$ & & Cortile di servizio \\
\hline & Ingressi carrai secondari & & Cortile d'onore \\
\hline & Ingressi carrai principali & & Volume edilizio basso \\
\hline & Ingressi pedonali & & Volume edilizio alto \\
\hline \multirow{2}{*}{ * } & \multirow{2}{*}{$\begin{array}{l}\text { Spazi di cortile improntati ad un chiaro } \\
\text { disegno architettonico rispondente a } \\
\text { intenzioni di prestigio }\end{array}$} & & Salone d'onore \\
\hline & & & $\begin{array}{l}\text { Spazi di rappresentanza adiacenti al salone } \\
\text { d'onore. }\end{array}$ \\
\hline & Scale di servizio & & Scalone d'onore \\
\hline
\end{tabular}

\section{Complessità delle operazioni di rilievo e restituzione di spazi articolati}

La documentazione grafica è uno strumento indispensabile per lo studio e l'analisi del patrimonio architettonico e, in misura ancora maggiore, per l'analisi di forme e spazi geometricamente complessi [Almagro 2019, p. 24].

Prima dell'avvento delle tecniche di rilevamento laser scanner 3D l'elaborazione dei dati di rilievo di complessi architettonici caratterizzati da una grande varietà di superfici d'involucro rappresentava un compito di difficile soluzione [Herráez et al. 20 I0, p. I8]. L'efficacia di tali tecniche è basata sull'acquisizione massiccia di dati, una rete o nuvola di punti utile all'acquisizione della geometria 3D nel suo complesso: tuttavia, l'utilizzo della tecnologia laser scanner 3D in spazi articolati implica l'adozione di una serie di precauzioni atte a ottenere dati accurati.

Prima di tutto, è essenziale realizzare una programmazione delle stazioni di scansione, tenendo conto di due parametri principali: la sovrapposizione tra le scansioni e l'assenza di punti d'ombra. La distanza tra le diverse stazioni è un fattore importante, che riduce i problemi nelle fasi di manipolazione delle scansioni e assicura una nuvola di punti efficace. [Ogawa, Hori 2019, p. 537]. Una distanza da circa 6 a 15 metri tra le scansioni, di solito, assicura una sovrapposizione sufficiente, a meno che le caratteristiche geometriche dello spazio non suggeriscano distanze minori. È raccomandato [Hajian et al. 20 I 0, pp. 265-272] che almeno tre punti di riferimento siano visibili tra una ripresa e l'altra. L'uso di sfere di riferimento facilita notevolmente il processo e le operazioni additive delle nuvole di punti. In questo caso, oltre alla programmazione iniziale delle scansioni, è necessario aggiungere il posizionamento strategico delle sfere, in modo che tra due scansioni consecutive vi siano tre sfere comuni a entrambe.

Il rilevamento di queste articolate sequenze di spazi è stato condotto su uno degli edifici presi in esame, palazzo Capris di Ciglié, per il quale è stata progettata e realizzata una acquisizione di dati completa, atta alla restituzione grafica.

Per elaborare la planimetria del palazzo Capris di Ciglié, è stato seguito un protocollo d'azione in funzione della complessità dell'impianto architettonico, della varietà delle superfici a volta, della fitta ornamentazione barocca, delle differenze di luce tra l'interno e l'esterno e della minimizzazione dei punti ciechi. Le scansioni sono state programmate in modo che ognuna di esse fosse centrata sotto ciascuna volta per evitare zone d'ombra, con una sovrapposizione reciproca del 48,9\% (fig. 7). Per assicurare la perfetta unione delle nuvole di punti, sono state utilizzate delle sfere di riferimento. La posizione di queste ultime è stata precedentemente programmata secondo due premesse: tre scansioni consecutive 
Fig. 7. Palazzo Capris di Cigliè. Localizzazione in pianta delle stazioni di scansione interne all'edifcio, piano terra (elaborazione grafica Concepción López González).

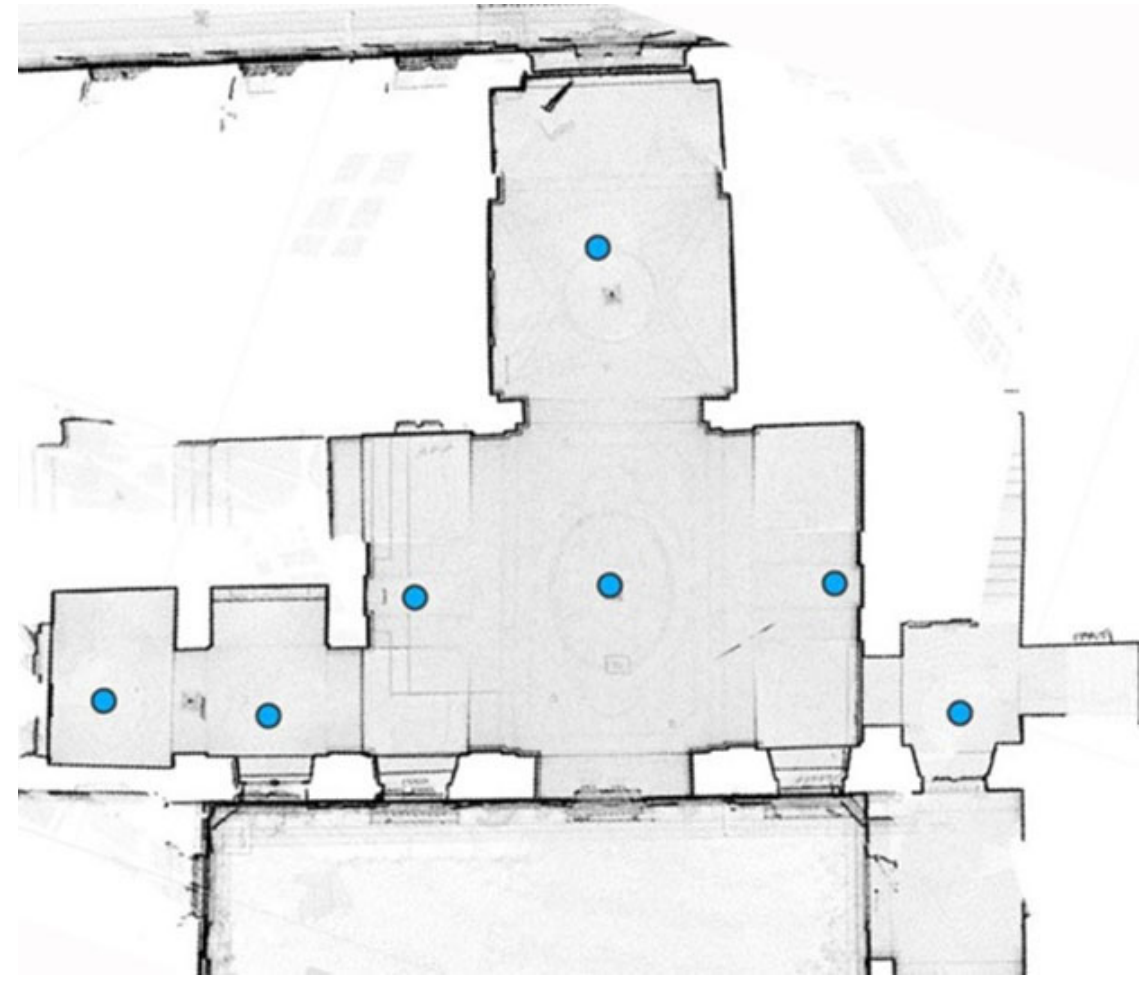

dovevano includere le stesse tre sfere; le sfere non dovevano essere allineate per formare piani passanti per tre punti (fig. 8). Le scansioni dall'esterno (dalla strada e dal cortile) sono state effettuate di fronte agli accessi per assicurare una sufficiente visibilità delle sfere situate all'interno. Infine, sono state fatte 9 scansioni del complesso, configurando un campo visivo orizzontale completo $\left(360^{\circ}\right)$ con una risoluzione di $1 / 8,(12 \mathrm{~mm}$ a $10 \mathrm{~m})$, un errore medio di I,6 mm e un totale di 100.। I5.79I punti nella nuvola finale.

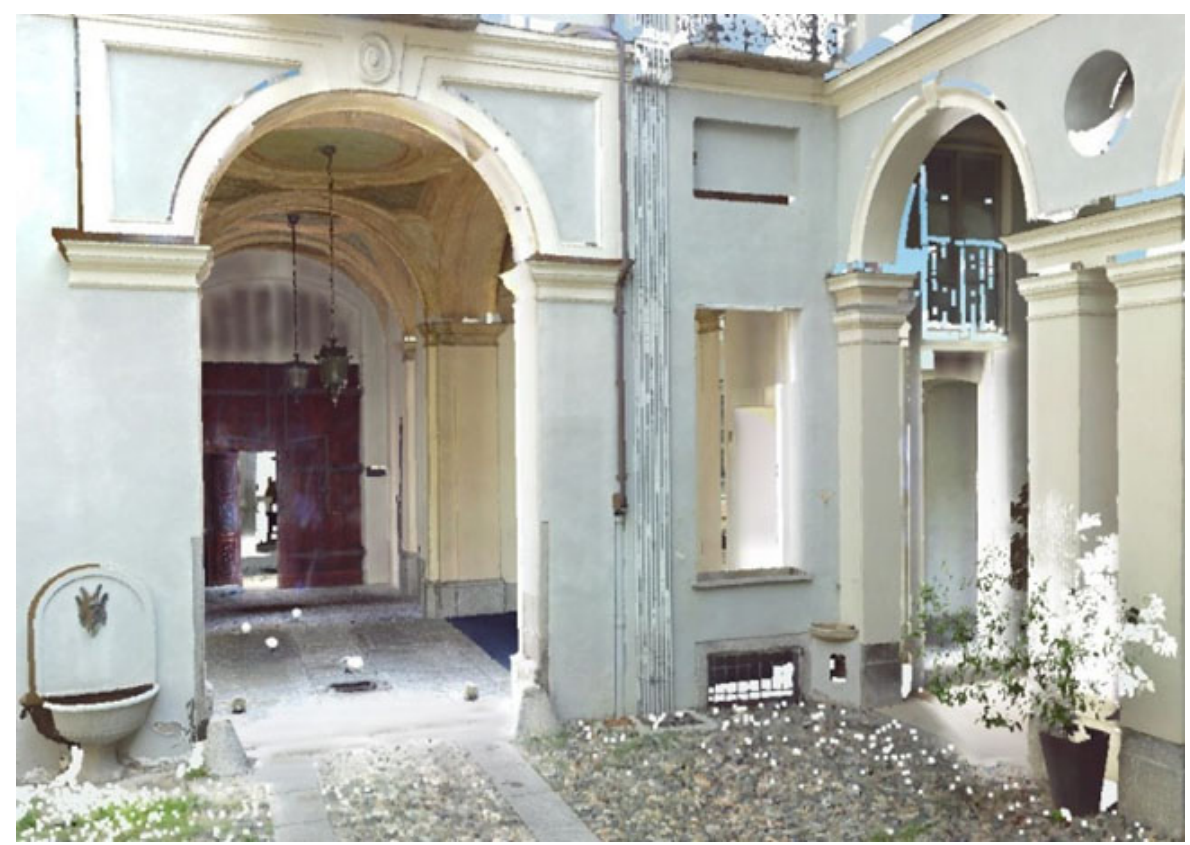

Fig. 8: Palazzo Capris di Cigliè. Posizionamento delle sfere di riferimento in una immagine della

nube di punti (elabora-

zione della nuvola dei

punti Concepción López González). 


\section{Palazzo Capris di Cigliè}

II palazzo Capris di Cigliè, la cui costruzione viene datata attorno al 1730 e attribuita a Gian Giacomo Plantery (1680-1756), viene realizzato in seguito alle profonde riplasmazioni del tessuto edilizio dell'isolato Santa Maria, definito dalle attuali vie Santa Maria, Botero, Stampatori e Barbaroux. II palazzo, con gli attigui palazzi Perucca della Rocchetta eVillanis, "costituisce un'importante sequenza di edifici settecenteschi, caratterizzanti il tessuto e l'ambiente di via Botero" [Politecnico di Torino 1984, p. 305] (fig. 9).

Le due facciate su strada del palazzo, costruite in aderenza alle prescrizioni atte a garantire uniformità architettonica e allineamenti in altezza [Cavallari Murat 1957, p. 323] (il cornicione si attesta a circa 18 metri di altezza), vengono definite da Augusto Cavallari Murat di gusto "un po' freddamente neoclassicheggiante" [Cavallari Murat 1957, p. 336]. II prospetto principale, privo - rispetto a tante realizzazioni coeve - dellimpostazione a lesene con ordini sovrapposti, è impostato assialmente sul portone d'ingresso (fig. I0) e diviso da semplici cornici marcapiano in tre livelli con mezzanino; i pochi balconi, strategicamente posizionati, si sviluppano con dimensioni inferiori al metro, dovendo venire incontro alle dimensioni della via. Dal punto di vista distributivo si nota una più sciolta organizzazione degli spazi rappresentativi, articolati in andito e atrio - coperti rispettivamente da una coppia di piccole volte stellari e una volta a fascioni - e scalone principale, concatenato scenograficamente all'atrio e disposto perpendicolarmente alla facciata principale. L'atrio, impostato su uno schema a fasce interrotte nel campo centrale, sembra sottolineare i flussi e le dinamiche del cerimoniale di ricevimento, enfatizzando l'assialità del percorso di ingresso con lo spazio del cortile d'onore (fig. 5). Quest'ultimo, rispetto all'impostazione originaria planteriana, ha perso la propria simmetria, così come descrive Paolo Cornaglia [2003, p. I6], a causa della costruzione successiva di una manica porticata [7], denunciata anche dal fondersi di elementi decorativi del XVIII e del XIX secolo. II fondale presenta un ulteriore spazio voltato al piano terra, in asse al portone principale, aperto verso la retrostante corte rustica.

Il piano nobile, distribuito strategicamente nelle due maniche perpendicolari (su strada e su cortile) dall'approdo dello scalone d'onore, presenta un'inedita soluzione per il posizionamento del salone, che a differenza degli altri esempi presi in considerazione, occupa interamente la manica su cortile. A tal proposito va ricordato che la posizione di tale ambiente non è del tutto certa, a causa dei pesanti bombardamenti del 1942, che hanno causato il crollo della manica interna e del secondo piano del palazzo [Bellaria 2007, p. 27]: essa è ipotizzata sulla base dell'organizzazione attuale degli spazi, che registrano in tale posizione un ambiente unico voltato a padiglione, e delle dimensioni ridotte degli ambienti collocati nella manica su strada (ancora nel loro stato originale, benché oggetto di un recente restauro [8]), che denunciano l'articolazione degli ambienti di un appartamento [Briolo 1822, pp. 71, 72].

Fig. 9. 1730, Gian Giacomo Planteri (attribuito): Palazzo Capris di Cigliè, via S. Maria I (elaborazione grafica Fabrizio Natta).
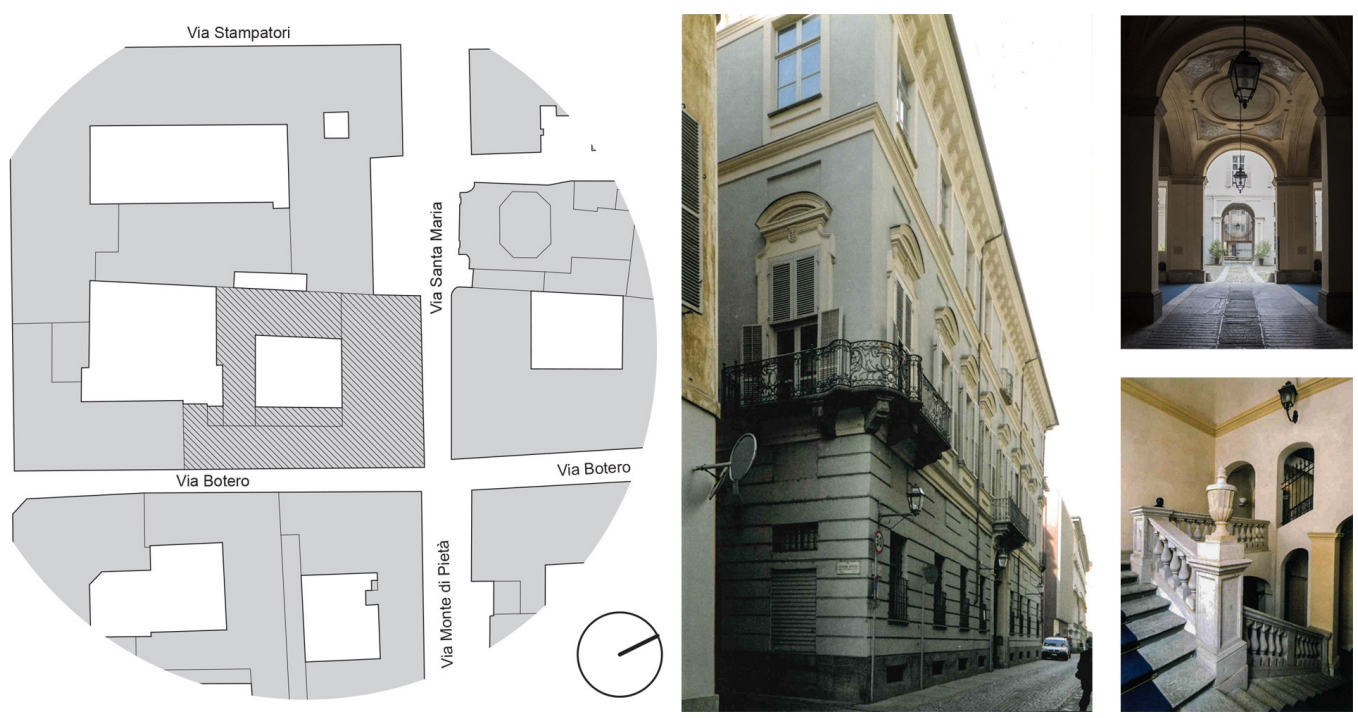
Fig. 10. Palazzo Capris di Cigliè, restituzione della facciata a partire dalla nuvola di punti (elaborazione grafica Fabrizio Natta).

Fig. I I. Palazzo Capris di Cigliè, restituzione della pianta del piano terreno completa di corte d'onore e accesso alla corte rustica e sezione in asse rustica e sezione in asse
al portone di accesso (elaborazione grafica Fabrizio Natta)
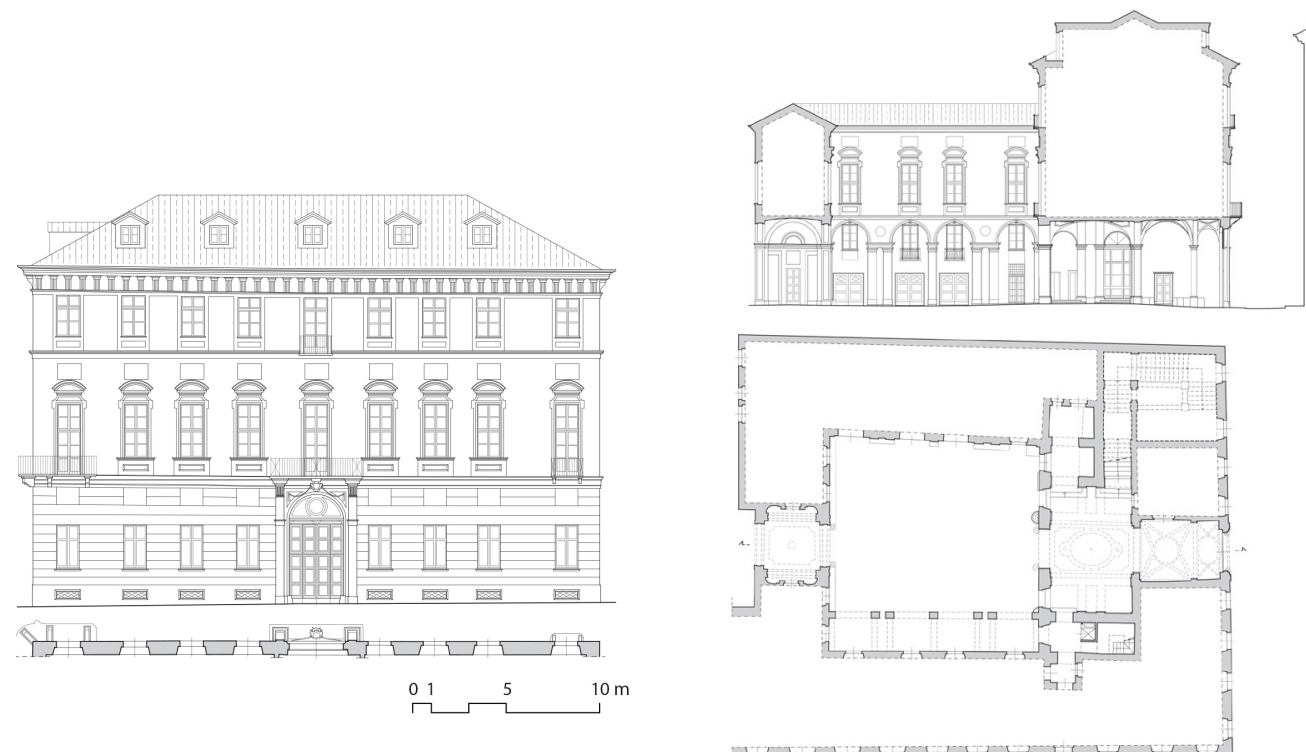

$\stackrel{0}{\overbrace{1}^{1}} \overbrace{}^{5}$ m

\section{Conclusioni}

Lo studio, attualmente in fase di svolgimento, vedrà nelle fasi successive del lavoro la realizzazione degli schemi relativi a una più ampia serie di casi studio, al fine di consentire un puntuale confronto tra gli edifici che presentano caratteristiche distributive simili e di estrapolare schemi di carattere generale, sulla base dei quali fornire una catalogazione completa degli edifici censiti all'interno del tessuto storico della città. Gli intrecci che saranno evidenziati dalle attività di rilievo e dall'analisi delle fonti storiche e archivistiche, attualmente in fase avanzata di svolgimento, agevoleranno una revisione degli schemi e l'integrazione di ulteriori funzioni, che contemplino, per esempio, l'organizzazione delle attività commerciali al piano terra, sempre più diffuse nel periodo barocco o ancora la distribuzione degli appartamenti da pigione nei piani successivi a quello nobile.

\section{Crediti}

II presente contributo, di cui gli autori hanno condiviso l'impianto metodologico, è stato redatto da Marco Vitali (par. Esigenze del percorso cerimoniale e organizzazione distributiva), Giulia Bertola (par. Tipologia e schematizzazione grafica), Concepción López González (par. Complessità delle operazioni di rilievo e restituzione di spazi articolati), Fabrizio Natta (par. Palazzo Capris di Cigliè).

\section{Note}

[I] La ricerca, diretta da Roberta Spallone e Marco Vitali, attualmente prosegue con la preziosa collaborazione della prof.ssa Concepción López González (che si è unita al gruppo grazie al progetto di collaborazione internazionale Nuevas tecnologías para el análisis y conservación del patrimonio arquitectónico, finanziata dal ministero della Scienza, Innovazione e dall'Università di Spagna), dalle assegniste di ricerca Giulia Bertola e Francesca Ronco e da Fabrizio Natta, dottorando.

[2] Ci si riferisce, a tal proposito, alla pianta di di Roma di Giovanni Battista Nolli ( 1748), a quella di Padova di Giovanni Valle (1779 1784), e anche ad alcuni esempi in sede internazionale, sebbene precedenti, come la pianta di Parigi di Boullet e Blondel (1676).

[3] Ci si riferisce allo schema redatto per il palazzo Capris di Cigliè, che richiama gli schemi dei palazzi Perucca della Rocchetta, Villanis, e molti altri.

[4] Ci si riferisce allo schema redatto per il palazzo Vallesa della Martiniana, che richiama gli schemi dei palazzi provana di Collegno e Carignano.

[5] Ci si riferisce allo schema redatto per il palazzo Mazzonis, che richiama gli schemi dei palazzi Coardi di Carpenetto, Barolo, Martini di Cigala, nonché alcuni edifici di produzione minore, e che evoca, sebbene con alcune differenze, gli schemi con doppio atrio, come quelli dei palazzi Cavour e Novarina di San Sebastiano. 
[6] Ci si riferisce allo schema redatto per il palazzo Saluzzo Paesana, in analogia con i palazzi Graneri e Asinari di San Marzano.

[7] Archivio storico della città di Torino, Progetti edilizi, I 853, 72, "Porticato".

[8] II progetto di restauro, realizzato con il contributo economico del Ministero per i Beni e le Attività Culturali, è stato condotto dagli architetti Vairano e Diena per adeguare il palazzo alla nuova sede della Fondazione dell'Avvocatura Fulvio Croce (2003-2005).

\section{Riferimenti bibliografici}

Almagro A. (2019). Medio siglo documentando el patrimonio arquitectónico con fotogrametría. In EGE Revista de Expresión Gráfica en la Edificación, n. II, pp. 4-30.

Ballaria E. (2007). Palazzo Capris e dintorni d'arte. Percorsi di identità barocca. Torino: Fondazione Cassa di Risparmio di Torino e della Reale Mutua Assicurazione.

Briolo G. (1822). Nuova guida dei forestieri per la Reale Città di Torino. Torino: Fratelli Reycend.

Cavallari Murat A. (1957). Gian Giacomo Plantery, architetto barocco. In Atti e Rassegna Tecnica della Società degli Ingegneri e degli Architetti in Torino, XI (n. 7), pp. 313-346.

Cifani A. Monetti F. (1989a). Il palazzo Vallesa di Martiniana. Da dimora signorile a sede sociale l'evoluzione di un palazzo in Torino. Torino: Sip.

Cifani A. Monetti F. (1989b). Palazzo Valperga Galleani di Barbaresco a Torino. Torino: Editris.

Cornaglia P. (2003). Guida ai cortili di Torino. Torino: Anteprima.

Griseri A. (1995). Il Palazzo Saluzzo Paesana.Torino: Allemandi.

Hajian H., Becerik-Gerber B. (2010). Scan to BIM: Factor Affecting Operational and Computational Errors and Productivity Loss. In 27th International Symposium on Automation and Robotics in Construction, pp. 265-272. Los Angeles: ISARC.

Herráez Boquera J., Navarro Esteve P., Denia Ríos J. L. (20 I0). Fundamentos y aplicaciones de la tecnología de Escáner Láser para documentación y restauración del patrimonio. Algunos ejemplos de aplicación en La Comunidad Valenciana. In A. Alcántara Onofre, A. M. Lara Gutiérrez (a cura di). Implementación de nuevos métodos de documentación y registro fotogramétrico digital para la protección y puesta en valor del patrimonio monumental mexicano, pp. 17-41. Ciudad de México: Universidad Politécnica de Valencia.

Magnaghi A. (1992). Torino: mappa concettuale della città antica ottenuta mediante mosaico delle piante degli edifici ricavate da diverse fonti iconografiche. In Atti e rassegna tecnica della Società degli ingegneri e degli architetti in Torino, XLVI (n. I0- I2).

Ogawa T., HoriY. (2019). Comparison with accuracy of terrestrial laser scanner by using point cloud aligned with shape matching and best fitting methods. In The International Archives of the Photogrammetry, Remote Sensing and Spatial Information Sciences, 8th Intl. Workshop 3D-ARCH 3D Virtual Reconstruction and Visualization of Complex Architectures, vol. XLII-2M9, Bergamo 6-8 February 2019, pp. 535-54I. Bergamo: ISPRS.

Pedrini A. ( 1955). Portoni e porte maestre in Piemonte: secoli XVII e XVIII. Torino: Pozzo Salvati Gros Monti.

Politecnico di Torino, Istituto di Architettura Tecnica (1968). Forma urbana ed architettura nella Torino barocca: dalle premesse classiche alle conclusioni neoclassiche, 2 voll., 3 tomi, ricerca diretta da A. Cavallari Murat, Torino: UTET.

Politecnico di Torino, Dipartimento Casa-Città (1984). Beni culturali ambientali nel Comune di Torino. Torino: Società degli ingegneri e degli architetti in Torino.

Spallone R., Vitali M. (2017). Volte stellari e planteriane negli atri barocchi in Torino. Ariccia: Aracne.

\section{Autori}

Marco Vitali, Politecnico di Torino, marco.vitali@polito.it

Concepción López González, Universitat Politècnica de València, mlopezg@ega.upv.es

Giulia Bertola, Politecnico di Torino, giulia.bertola@polito.it

Fabrizio Natta, Politecnico di Torino, fabrizio.natta@polito.it

Per citare questo capitolo:Vitali Marco, López González Concepción, Bertola Giulia, Natta Fabrizio (202I). Percorsi cerimoniali e organizzazione distributiva nei palazzi barocchi torinesi. Palazzo Capris di Ciglié/Ceremonial ways and distribution in the baroque palaces of Turin. Palazzo Capris di Ciglié. In Arena A., Arena M., Mediati D., Raffa P. (a cura di). Connettere. Un disegno per annodare e tessere. Linguaggi Distanze Tecnologie. Atti del $42^{\circ}$ Conve Technologies. Proceedings of the $42^{\text {th }}$ International Conference of Representation Disciplines Teachers. Milano: FrancoAngeli, pp. I 274- 1293. 


\title{
Ceremonial Ways and Distribution in the Baroque Palaces of Turin. Palazzo Capris di Ciglié
}

\author{
Marco Vitali \\ Concepción López González \\ Giulia Bertola \\ Fabrizio Natta
}

Abstract

Starting from the arguments that link the spaces for mixed use (public-private) of the noble palaces to the quality and decorum of the urban scene, we try here, on the basis of previous research on complex vaulted systems, to identify in the repertoire of Baroque buildings surveyed and found within the historical fabric of the city ofTurin, some recurring organizational patterns as evidence of the main lines of development and transformation of the design archetypes in accordance with the formal aesthetic taste and changing functional needs. In this sense, the spaces of the palace dedicated to the ceremonial entrance and reception participate in the definition of a fundamental nucleus, generally designed with great compositional and scenic unitary effort, assuming a clear individuality in the structure of the palace. On one of the buildings taken into consideration for the graphical schematization, Palazzo Capris di Cigliè, we will test a methodology of laser scanner survey and restitution aimed at the implementation of the schemes in the following phases of the research.

Keywords

entrance ceremony, baroque architecture, laser scanner survey, representation.
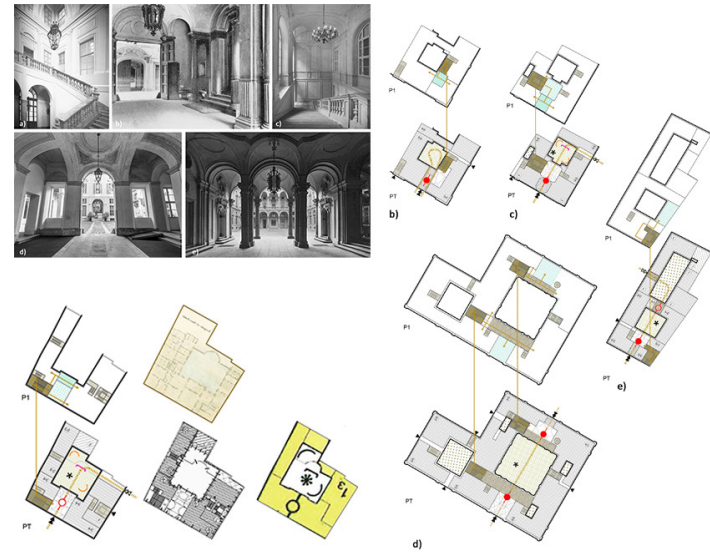

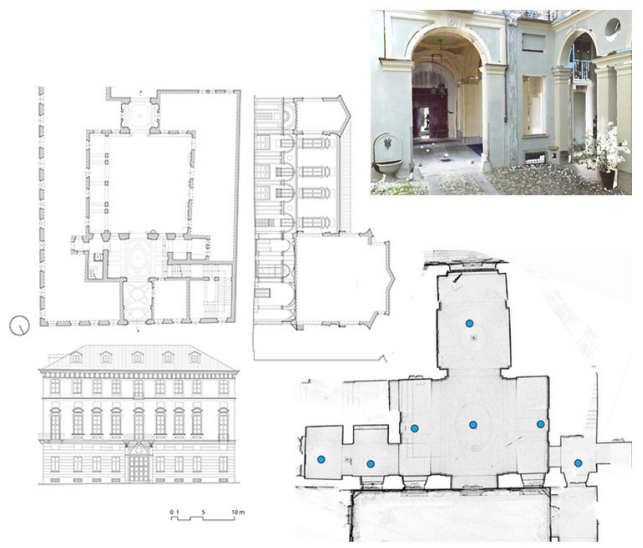

doi.org/ | 0.3280/oa-693.72 


\section{Introduction}

The present study is rooted in the broader research that, for about ten years now, has been conducted on complex vaulted systems [ $I]$ and that has seen the research group engaged in the analysis and study of the relationship between geometry, shape, and design in the composition and implementation of the atria of noble palaces within the historical fabric of the city of Turin in the Baroque period [Spallone, Vitali 20 17]. Starting from the considerations that link the spaces for mixed-use (public-private) of the noble palaces to the quality and dignity of the urban scene -as witnessed by much of the cartographic production of the Baroque period, both nationally [2] and locally- we try here, also in the wake of previous studies conducted in this sense [Politecnico di Torino 1968, pp. 616-667], to identify, in the repertoire of buildings cataloged and surveyed, some recurrent organizational schemes as evidence of the main lines of development and transformation of the project archetypes in adherence to the formal aesthetic taste and the changing functional needs.

In this sense, the spaces of the palace dedicated to the entrance and reception ceremonial (atrium, auxiliary spaces, and connection with the court of honor, such as hallways, galleries, etc., the rustic courtyard, the staircase, and the main room and rooms connected to it at the piano nobile) participate in the definition of a fundamental design core, generally defined with great compositional and scenic unity, assuming a clear individuality in the structure of the palace (fig. I).

Fig. I.The ceremonial way of Turin's baroque palace ges: a) grand staircase of the Palazzo Vallesa della Martiniana; b) Atrium of Martiniana; b) Atrium of the Palazzo Mazzonis; $c$ grand staircase of the Palazzo Valperga Gallean di Barbaresco; d) Atrium of the Palazzo Capris c Ciglié; e) Atrium of the Palazzo Saluzzo Paesana.
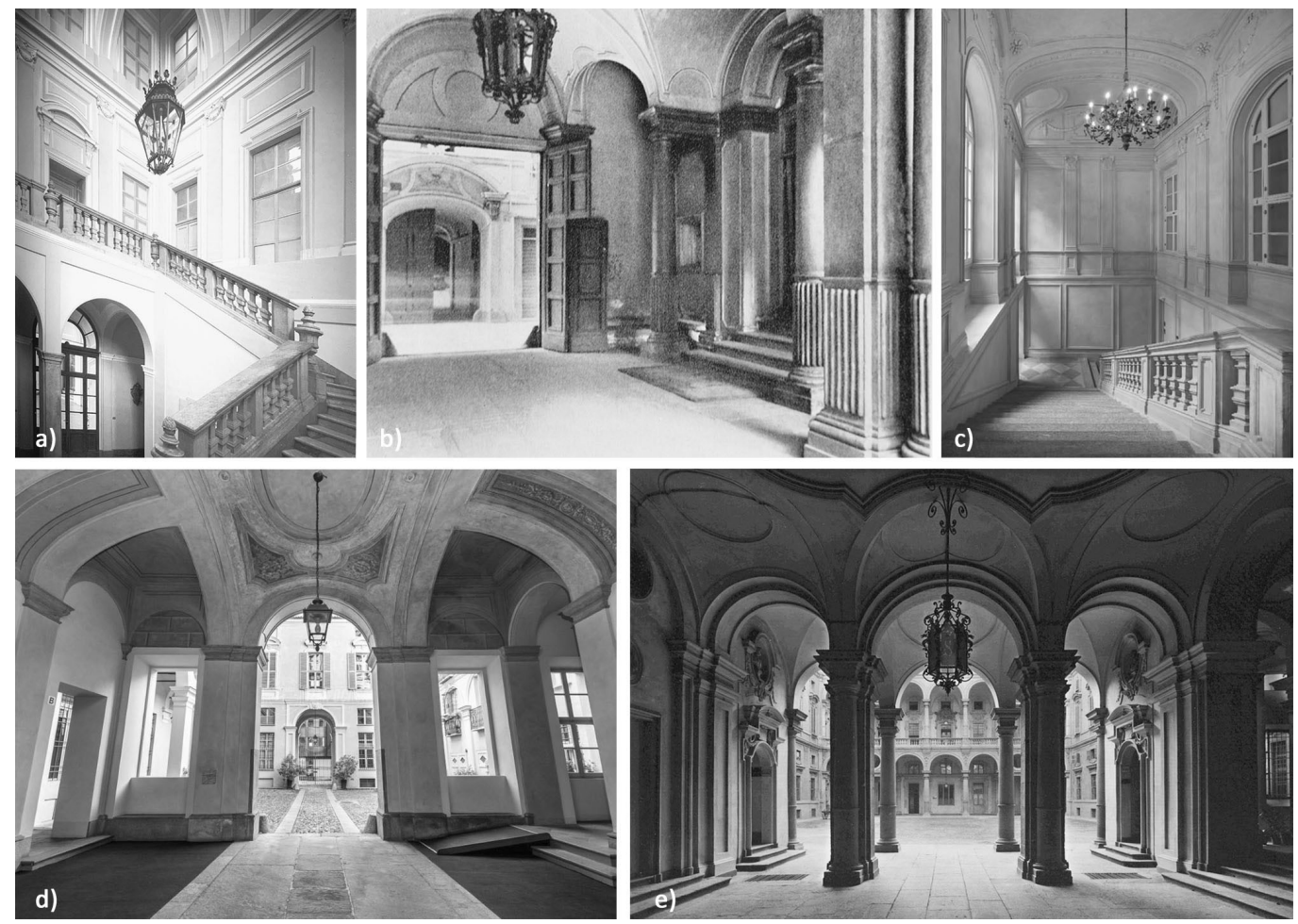

\section{Requirements of the ceremonial way and distribution}

The noble baroque buildings of the historical fabric of the city of Turin testify to compositional attitudes that, on the one hand, collect the instances related to the recovery and restoration of old buildings, usually completed with small expenses and compositional solutions of little relevance, on the other hand, face the reconfiguration of interior spaces, and in particular the central core used for the entrance and reception ceremony, proposing original design solutions. They define unitary but distinct spaces, which through the mechanism of spatial interconnection constitute systems with a representative content, characterized 
by different distributive and functional solutions and adapted to the changing needs of the ceremonial.

The identification of these archetypes and their schematization passes through an analysis that takes into consideration multiple aspects of the construction:

- the plan diagrams of the building (ground floor and main floor), partly taken from the reference cartography [Magnaghi 1992], partly from archival documents of the design, survey, and historical descriptions;

- the composition of the elevations, which shows, through the presence and organization of the mezzanine floors, the harmonization of ceremonial spaces (some of which are double height, as shown in the drawings and sections of the project) and service spaces (figs. 2-3), connected to them through secondary staircases and hidden paths;

- the schemes that connect the organization of the palace with the structure of the block and the distribution of entrances and courts (of honor and rustic), defined by the mappe filologico-congetturali [Politecnico di Torino 1968, II, A] and by the tables related to Contesti di interesse culturale e ambientale [Città di Torino 1994, tav. 2].
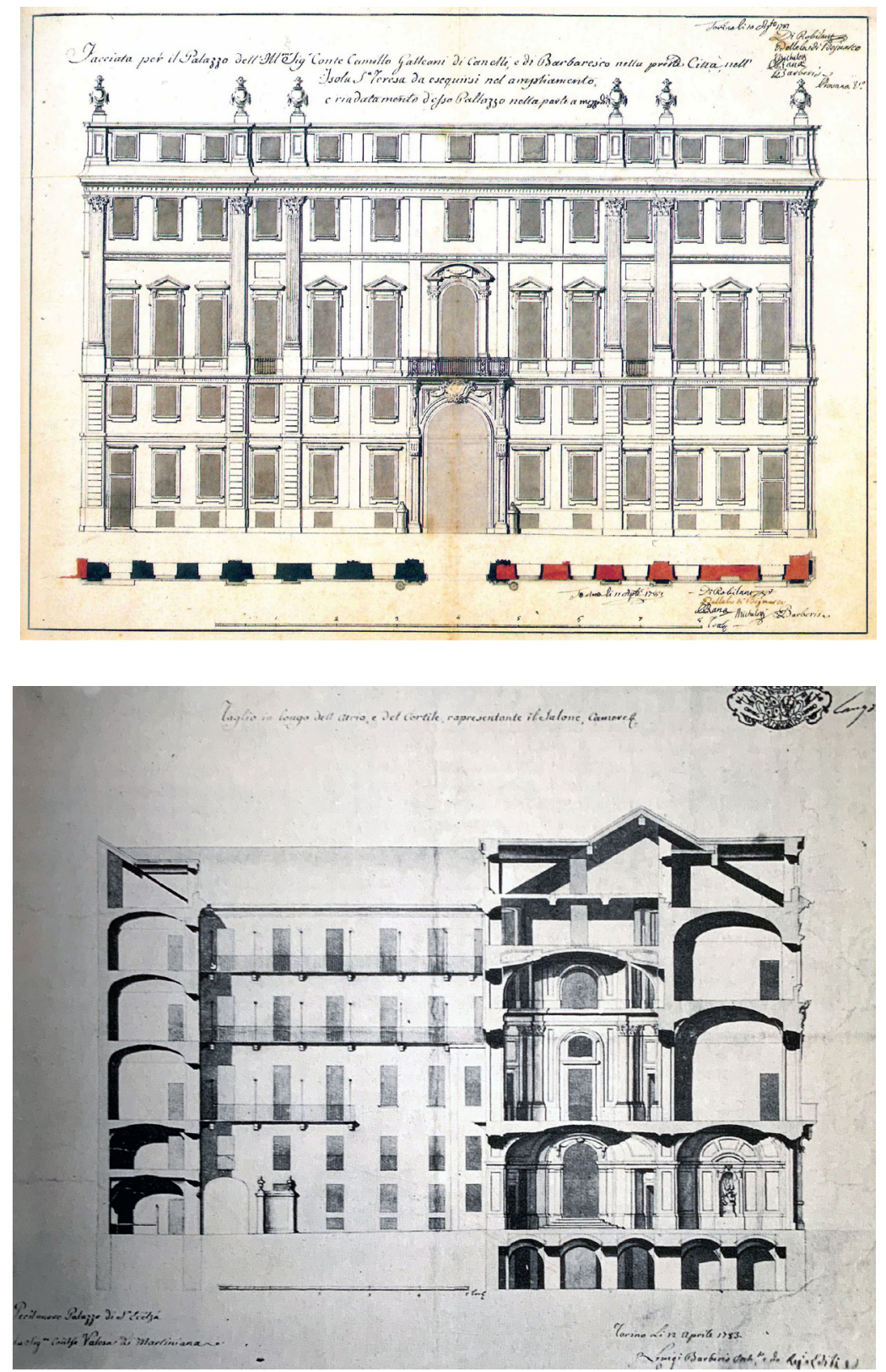
Fig. 4. Distributional scheme related to $\mathrm{Pa}$ lazzo Mazzonis: from the bottom, the scheme borrows, for the definition of the spaces on the ground floor: the information related to the mappe filologico-congetturali relative ai tessuti urban nell'ultimo quarto del Settecento [Politecnico di Torino 1968, II, A mappa 2] the moppe denomina 2], the mappe denominate Contesti upani di interesse ino 1994, Tav 2] for the (ino 1994, lav. 2], for the definition of the spaces on the upper floor one of the survey boards of the building, executed in 1845 [Archivio Storico del Comune di Torino, Tipi e dis., cart. 63, fasc. 9 , dis. I, tav III] (graphic elaboration Giulia Bertola).
The buildings that have been selected for the drawing up of the object of the scheme of the present study represent palaces with homogeneous characteristics, that see alternating vestibule on-road (or hallway, in the cases of minor architectural value [3]) and atrium on the courtyard [4] (with, in general, the consequent position of the main room), or vice versa [5], or even more complex schemes in which the previous elements are joined by galleries on the courtyard which distribute the staircase and disengage the main room at the piano nobile [6], scenographic elements of backdrop for the court of honor, connections with rustic courts and secondary driveways.

Finally, as evidence of buildings that escape to rigid typological cataloging, it has been studied the distributive scheme of Palazzo Valperga Galleani di Canelli and Barbaresco, which presents, probably by the complex events of enlargement and restructuring carried out in the second half of the eighteenth century, an original arrangement, in which the atrium, raised above the driveway and completely glazed, is transformed into a real main room on the ground floor, which communicates with a lounge on the upper floor through a grand staircase.
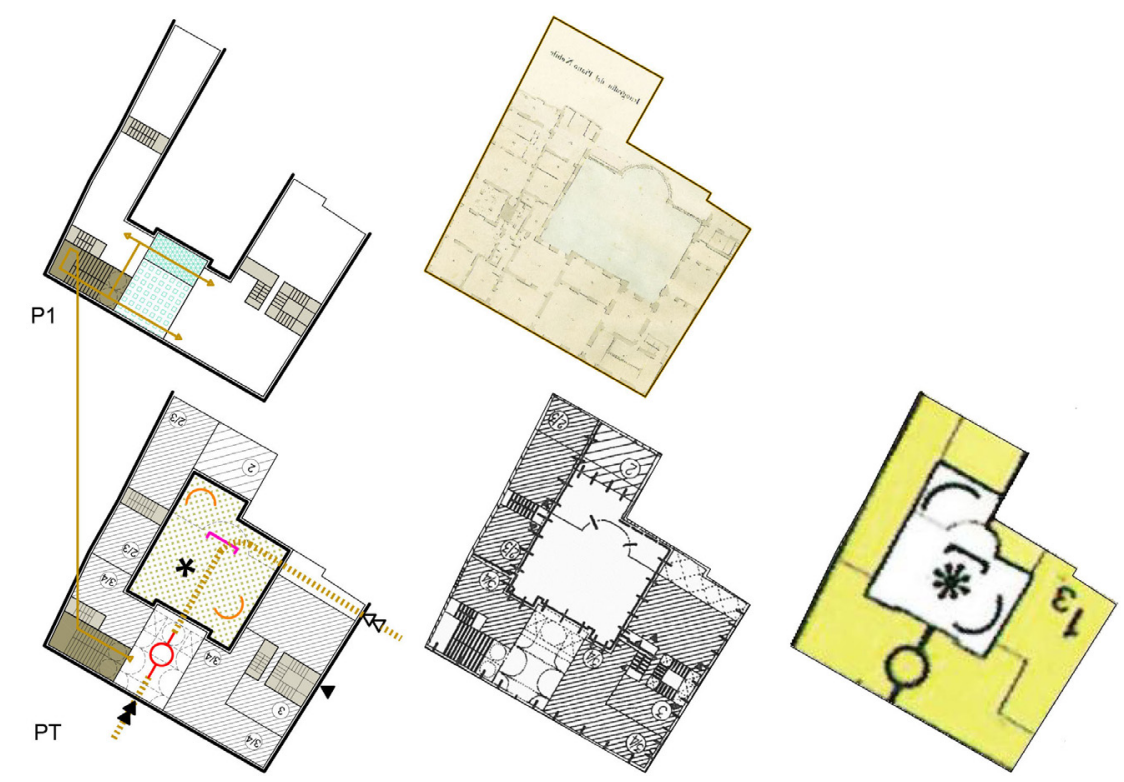

\section{Typology and graphic schemes}

The realization and comparison of distributional and conceptual schemes aimed at describing ceremonial ways and spaces was tested on five noble Turin palaces built between the end of the 17th century and the first decades of the 18th century: Palazzo Saluzzo Paesana [Griseri 1995], Palazzo Capris di Cigliè, Palazzo Mazzonis, Palazzo Vallesa di Martiniana [Cifani, Monetti 1989a], Palazzo Valperga Galleani di Barbaresco [Cifani, Monetti 1989b].

The graphic coding was conceived starting from the comparison and overlapping of the maps and cartography about the ground floors distribution (presented in the previous paragraph, fig. 4), which guaranteed a homogeneous basis for the five buildings, complete with information about distribution, stereometry, scenography, architectural connections, etc. Moreover, in-depth studies aimed at understanding the organization of the spaces on the piano nobile followed, based on historical surveys, archival drawings, historical descriptions (fig. 5).

For the outcomes, a diachronic criterion has been adopted, aimed at the valorization of the links between public (streets and squares) and private spaces (atrium and distribution elements) on the ground floor (represented through the projection on the ground of the 
vaulted systems that characterize them), the courtyard/s and the grand staircase. In this way, it has been tried to underline the character of heterogeneity of the spaces inside the different building cells focusing the attention on the design variety of the connections among the spaces because of the different flows of people, animals, things.

During the re-design process, it was necessary to use stereometric symbols, some taken from existing maps, others newly created. To these, distributional symbols were added, aimed at indicating flows within the horizontal circulation spaces (hallways, vestibules, passages, corridors, galleries), the vertical circulation spaces of honor and service (stairs and ramps), the private spaces (main room, accesses to apartments), (fig. 6).

About accesses and paths, main entrances distinct from the service entrances and the accesses to the palace apartments have been indicated, differentiating the pedestrian paths from those of the carriages.

To these symbols have been subsequently superimposed some others derived from the Ideogrammi della monumentalità [Politecnico di Torino 1968, vol. I, III; B, I] and recovered in the tables published in 1994 on the occasion of the project of the new town masterplan of Torino. Such elements describe the peculiar characters of spaces such as those of connection between the street and the courtyard, courtyard spaces architecturally conceived and responding to prestige intentions, often enriched by the presence of backdrops, and courtyard spaces belonging to different cells of the same block.

Fig. 5. Descriptive diagrams of the entrance ceremony related to the palaces: a) Mazzonis; b) Valperga Galleani di Barbaresco; c) Vallesa della Martirana: d) Saluzzo Paesana: e) Caris di Cigliè elaboration Giulia Bertola).
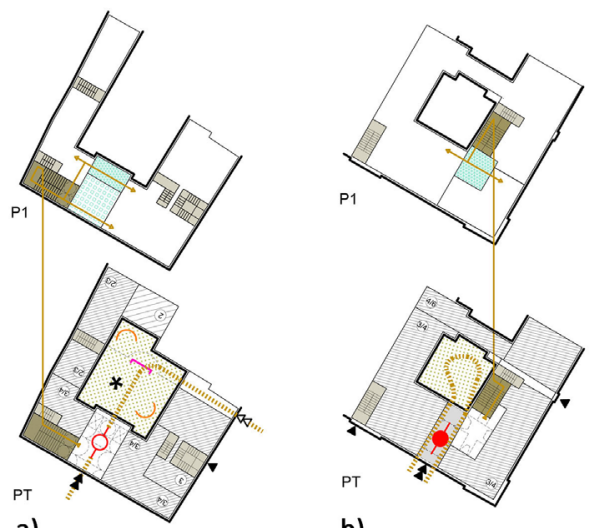

b)

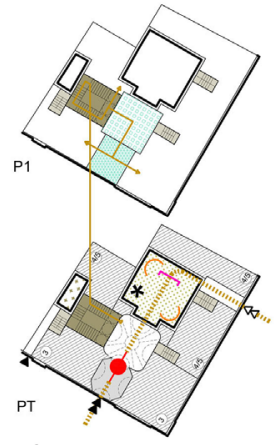

c)

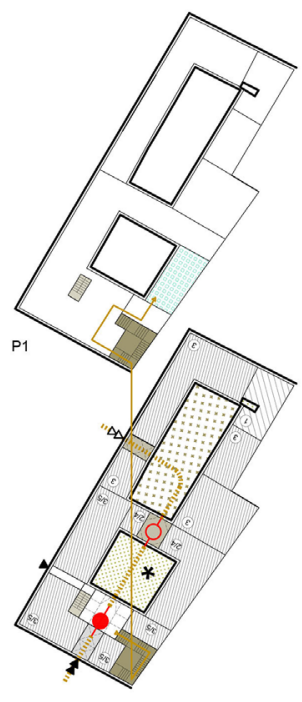

e) 
Fig. 6. Legend for the descriptive diagrams of the cerimonial path in the baroque palaces in Torino (graphic elaboration (graphic elabor

\begin{tabular}{|c|c|c|c|}
\hline & $\begin{array}{l}\text { Percorsi passanti al cortile sviluppati a doppia } \\
\text { altezza }\end{array}$ & & Distribuzione verticale \\
\hline- & $\begin{array}{l}\text { Percorsi passanti al cortile sviluppati a } \\
\text { semplice altezza }\end{array}$ & 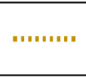 & Percorsi cerimoniali delle carrozze \\
\hline & Fondale di composizione architettonica chiusa & & $\begin{array}{l}\text { Volume edilizio alto delimitato da facciata con } \\
\text { coronamento }\end{array}$ \\
\hline & $\begin{array}{l}\text { Legami tra spazi di cortile appartenenti } \\
\text { a cellule diverse di uno stesso spazio }\end{array}$ & & Cortile di servizio \\
\hline & Ingressi carrai secondari & & Cortile d'onore \\
\hline & Ingressi carrai principali & & Volume edilizio basso \\
\hline & Ingressi pedonali & & Volume edilizio alto \\
\hline \multirow{2}{*}{ * } & \multirow{2}{*}{$\begin{array}{l}\text { Spazi di cortile improntati ad un chiaro } \\
\text { disegno architettonico rispondente a } \\
\text { intenzioni di prestigio }\end{array}$} & & Salone d'onore \\
\hline & & & $\begin{array}{l}\text { Spazi di rappresentanza adiacenti al salone } \\
\text { d'onore. }\end{array}$ \\
\hline & Scale di servizio & & Scalone d'onore \\
\hline
\end{tabular}

\section{Complex survey procedures and restitution of articulated spaces}

Graphic documentation is an indispensable tool to study the architectural heritage and, to an even greater extent, analyze geometrically complex forms and spaces [Almagro 20 I9, p. 24]. Before the advent of 3D laser scanner techniques, the processing of survey data of architectural complexes characterized by a wide variety of envelope surfaces represented a difficult task [Herráez et al. 20 10, p. 18]. The effectiveness of these techniques is based on the massive acquisition of data, a network or cloud of points necessary for the acquisition of the 3D geometry as a whole: however, the use of 3D laser scanner technology in articulated spaces implies the adoption of a series of precautions aimed at obtaining accurate data.

First of all, it is essential to plan the scanning stations, taking into account two main parameters: the overlap between the scans and the absence of shadow areas. The distance between stations is an important issue, which reduces problems in the scan processing stages and ensures an effective point cloud [Ogawa, Hori 20 I9, p. 537]. A distance of about 6 to I5 meters between scans ensures sufficient overlap unless the geometric characteristics of the space suggest smaller distances. It is recommended [Hajian et al 20I0, pp. 265-272] that at least three reference points are recognizable in two consecutive scans. The use of reference spheres greatly facilitates the process and addition of point clouds. In this case, it is necessary to add the strategic placement of the spheres so that between two consecutive scans there are three spheres common to both.

The survey of these articulated spaces sequences was realized on Palazzo Capris di Ciglié, one of the examined buildings: a complete data acquisition was planned and realized, suitable for graphic restitution.

A protocol of action was applied to elaborate the floor plan of the palace, according to:

- the complexity of the architectural layout;

- the variety of vaults;

- the dense Baroque decoration;

- the differences in light between the interior and exterior;

- the minimization of blind spots.

The scans were planned in a way that each scan was centered under each vault to avoid shadow areas, with a $48.9 \%$ mutual overlap (fig. 7). Reference spheres were used to ensure the perfect union of the point clouds. 
Fig. 7. Palazzo Capris di Cigliè. Location in plan of the scanning stations inside the building, ground floor (graphic elaboration Concepción López González).

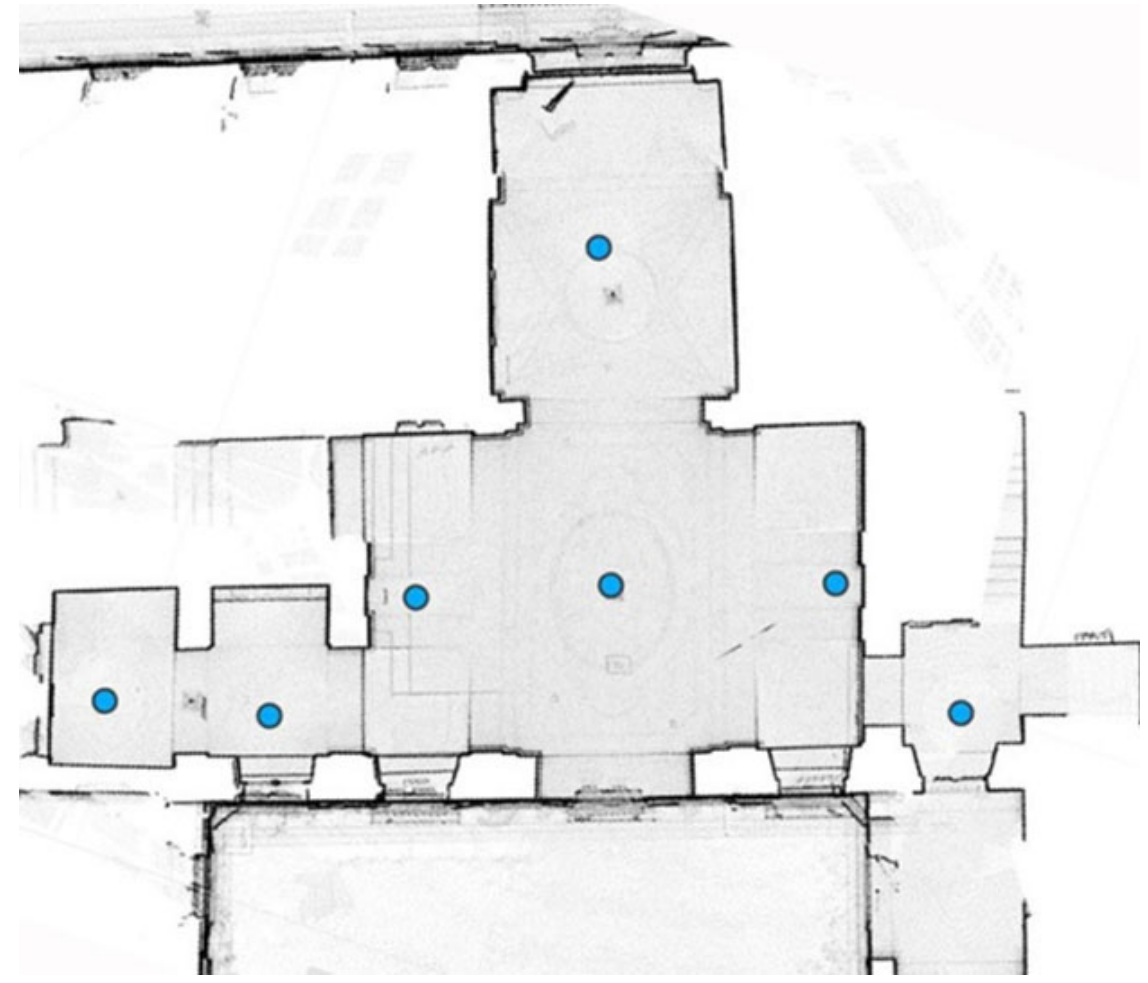

The spheres position was planned under two assumptions:

- three consecutive scans had to include a trio of spheres;

- the spheres did not have to be aligned to form planes passing through three points (fig. 8). Outside scans (from the street and courtyard) were performed in front of entrances to ensure sufficient visibility of the inside spheres. Finally, nine scans were made, configuring a full-horizontal field of view $\left(360^{\circ}\right)$ with a resolution of I/8 (12 mm at $\left.10 \mathrm{~m}\right)$, an average error of $1.6 \mathrm{~mm}$, and a total of $100,115,79 \mid$ points in the final cloud.

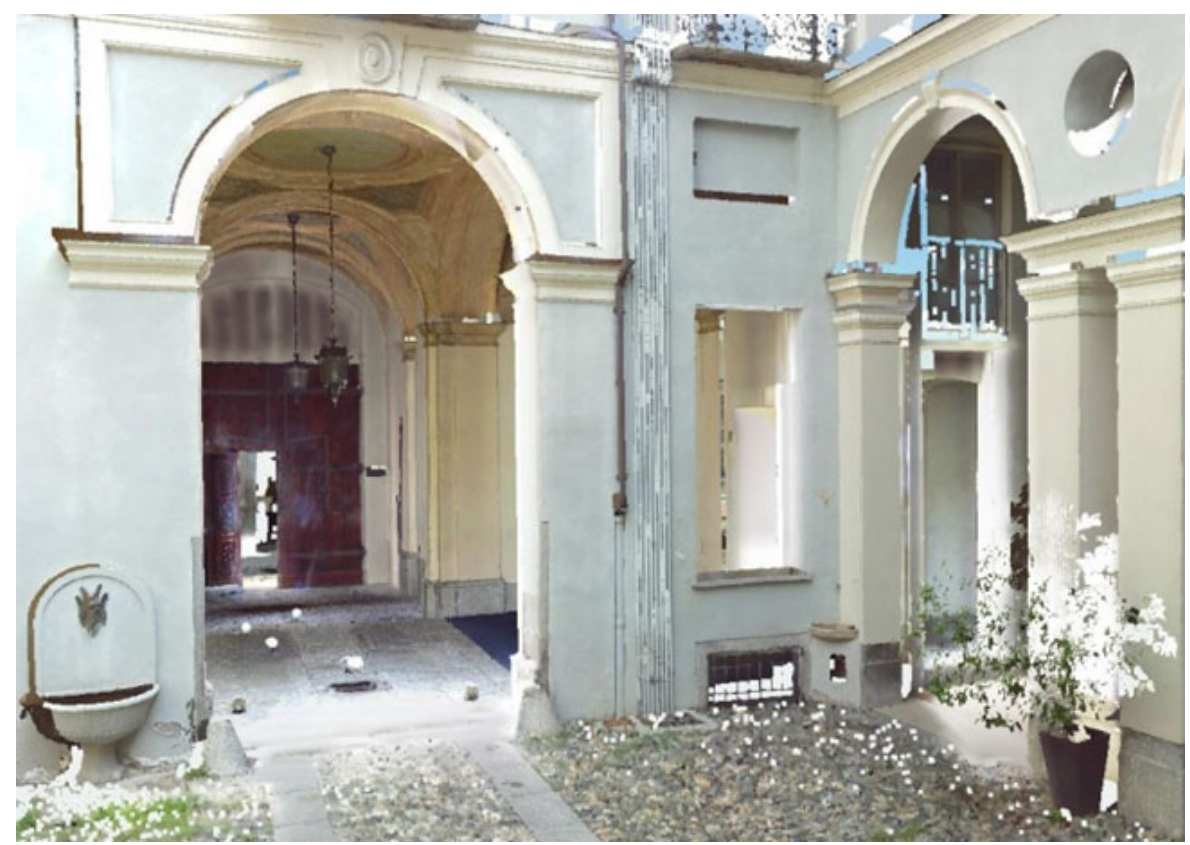

Fig. 8. Palazzo Capris di Cigliè. Positioning in reference spheres (processing of the (processing of the point González). 


\section{Palazzo Capris di Cigliè}

Palazzo Capris di Cigliè, whose construction is dated back around 1730 and attributed to Gian Giacomo Plantery (1680- I756), was built following the extensive reshaping of the building pattern of the Santa Maria block, defined by today's via Santa Maria, via Botero, via Stampatori and via Barbaroux. The palace, with the adjacent Palazzo Perucca della Rocchetta and Palazzo Villanis, "constitutes an important sequence of I 8th-century buildings, characterizing the structure and the environment of via Botero" [Politecnico diTorino 1984, p. 305] (fig. 9).

The two street façades of the palazzo, built in compliance with the prescriptions to guarantee architectural uniformity and height alignments [Cavallari Murat 1957, p. 323] (the cornice is about 18 meters high), are defined by A. Cavallari Murat as being in a "somewhat coldly neo-classical taste" [Cavallari Murat 1957, p. 336]. Compared to many contemporary constructions, the main façade lacks the pilaster strips with superimposed orders. It is set axially on the entrance door (fig. I0) and divided by simple stringcourses into three levels with a mezzanine; the few balconies, strategically positioned, are less than one meter wide, to accommodate the dimensions of the street.

From the distributional point of view, there is a fluid organization of the representative spaces, divided into vestibule and atrium - covered respectively by a pair of small star-shaped vaults and a banded vault - and the main staircase, scenically linked to the atrium and placed perpendicularly to the main façade. The atrium, based on a pattern of bands interrupted in the central field, seems to emphasize the flows and dynamics of the reception ceremony, highlighting the axiality of the entrance path with the space of the court of honor (fig. 5). Compared to the original layout by Plantery, the court has lost its symmetry, as described by Paolo Cornaglia [2003, p. 16], due to the construction of a portico [7], also evoked by the mixture of I8th and 19th-century decorative elements. The background presents a further vaulted space on the ground floor, on the axis of the main door, open towards the rustic courtyard behind.

The piano nobile, strategically distributed by the main staircase in two perpendicular sides (overlooking the street and the courtyard), presents an unusual solution for the positioning of the main room, which differs from the other examples considered, occupies the entire courtyard side. In this regard, it should be remembered that the position of this room is not entirely certain, due to the heavy bombing in 1942, which caused the collapse of the inner side and the second floor of the palace [Bellaria 2007, p. 27]: it has been hypothesized based on the current organization of the spaces, which in this position have a single room with a cloister vaulted ceiling, and of the reduced size of the rooms in the side facing the street (still in their original state, although recently restored [8]), which indicate the layout of the rooms in an apartment [Briolo 1822, pp. 71-72].

Fig. 9. 1730, Gian Giacomo Plantery (attributed) Palazzo Capris di Cigliè, via S. Maria I (graphic elaboration Fabrizio Natta).
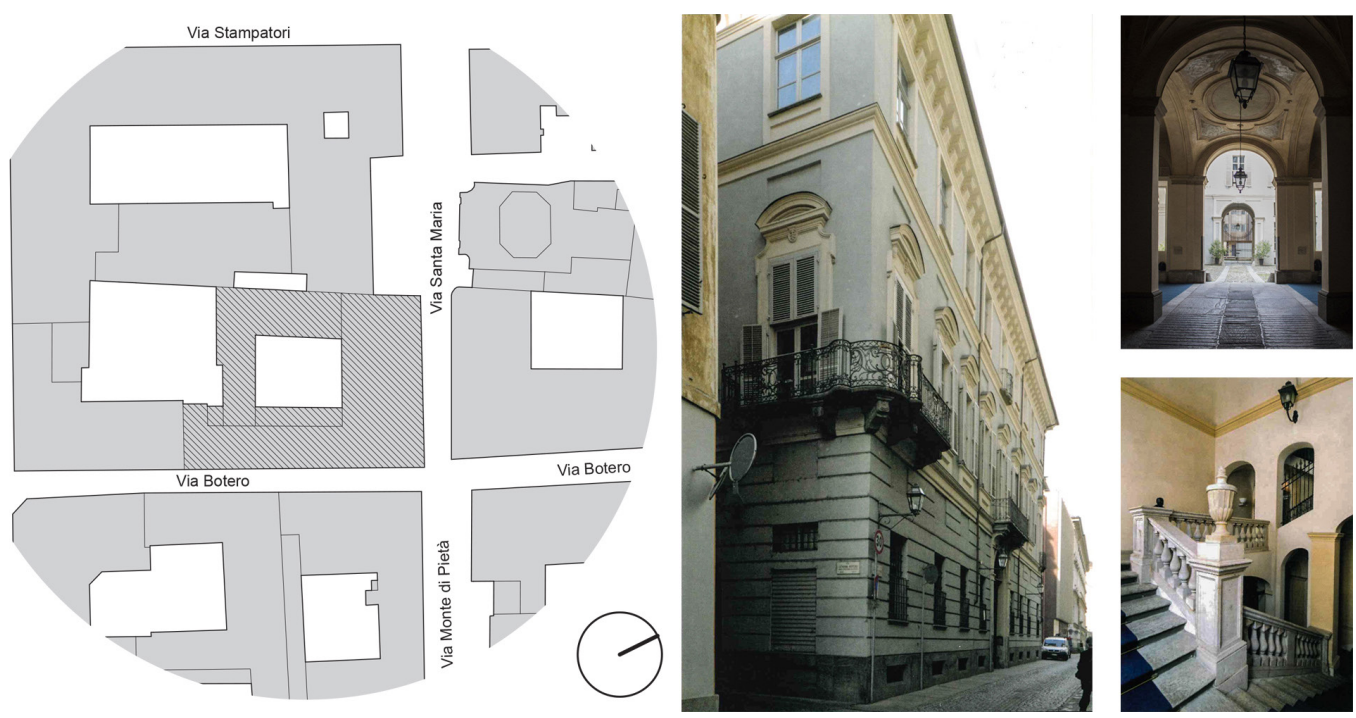
Fig. 10. Palazzo Capris di Cigliè, restitution of the facade from the point cloud (graphic elaboration Fabrizio Natta).

Fig. I I. Palazzo Capris di Cigliè, restitution of the Cinie, fhe ground floor clanplete with court complete with court the rustic courtyard the rustic courtyard, and section on the axis passing through the main entrance door (graphic elaboration Fabrizio Natta).
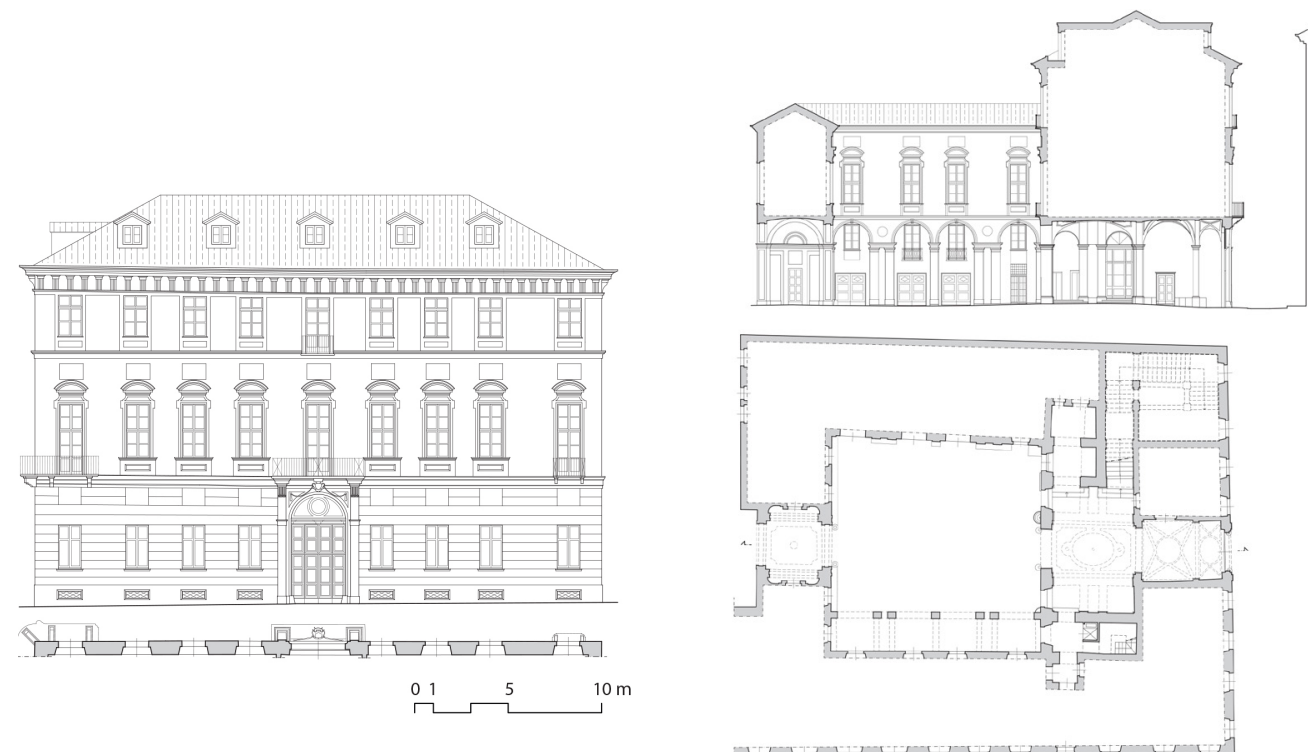

$\stackrel{0}{\overbrace{}^{1}} \sim^{5}$

\section{Conclusions}

The in-progress study will see, in the following phases, the realization of the schemes related to a wider series of case studies to allow a precise comparison between buildings that show similar distributional characteristics and to extrapolate general schemes, based on which to provide complete cataloging of the buildings surveyed within the historical fabric of the city. The interweaving that will be highlighted by the survey and the analysis of historical and archival sources, currently in an advanced stage of development, will facilitate a revision of the schemes and the integration of further functions, which contemplate, for example, the organization of commercial activities on the ground floor, increasingly common in the Baroque period, or the distribution of the apartments for rent on the floors following the main one.

\section{Credits}

The methodological framework was shared by the authors (Introduction, Conclusion); Marco Vitali wrote par. "Requirements of the ceremonial way and distribution", Giulia Bertola wrote par."Typology and graphic schemes", Concepción López González wrote par. "Complex survey procedures and restitution of articulated spaces", Fabrizio Natta wrote par. "Palazzo Capris di Cigliè".'

\section{Notes}

[I] The research, directed by Roberta Spallone and Marco Vitali, is currently ongoing with the precious collaboration of Prof. Concepción López González (who joined the group thanks to the international collaboration project Nuevas tecnologías para el análisis y conservación del patrimonio arquitectónico, financed by the Ministry of Science, Innovation and the University of Spain), by the research fellows Giulia Bertola and Francesca Ronco and by Fabrizio Natta, Ph.D. student.

[2] We refer, in this regard, to the map of Rome by Giovanni Battista Nolli ( 1748), to that of Padua by Giovanni Valle ( 1779 1784), and also to some international examples, although earlier, such as the map of Paris by Boullet and Blondel (1676).

[3] We refer to the scheme developed for the Capris Palace in Cigliè, which recalls the schemes of Perucca della Rocchetta, Villanis, and many other palaces.

[4] We refer to the scheme created for Palazzo Vallesa della Martiniana, which recalls the schemes of Provana di Collegno, and Carignano palaces.

[5] We refer to the scheme drawn up for Palazzo Mazzonis, which recalls the schemes of Coardi di Carpenetto, Barolo, Martini di Cigala palaces, as well as some minor buildings, and evokes, although with some differences, the schemes with double atrium, such as those of Cavour and Novarina di San Sebastiano palaces. 
[6] This refers to the scheme elaborated for Palazzo Saluzzo Paesana, similar to Graneri and Asinari di San Marzano palaces.

[7] Historical Archives of the City of Turin, Progetti edilizi, I853, 72, "Porticato".

[8]The restoration project, carried out with the economic contribution of the Ministry of Cultural Heritage and Activities, was conducted by architects Vairano and Diena to adapt the building for the new headquarters of the Fondazione dell'Awocatura Fulvio Croce (2003-2005).

\section{References}

Almagro A. (2019). Medio siglo documentando el patrimonio arquitectónico con fotogrametría. In EGE Revista de Expresión Gráfica en la Edificación, n. I I, pp. 4-30.

Ballaria E. (2007). Palazzo Capris e dintorni d'arte. Percorsi di identità barocca. Torino: Fondazione Cassa di Risparmio di Torino e della Reale Mutua Assicurazione.

Briolo G. (1822). Nuova guida dei forestieri per la Reale Città di Torino.Torino: Fratelli Reycend.

Cavallari Murat A. (1957). Gian Giacomo Plantery, architetto barocco. In Atti e Rassegna Tecnica della Società degli Ingegneri e degli Architetti in Torino, XI (n. 7), pp. 3I3-346.

Cifani A. Monetti F. (1989a). Il palazzo Vallesa di Martiniana. Da dimora signorile a sede sociale l'evoluzione di un palazzo in Torino. Torino: Sip.

Cifani A. Monetti F. (1989b). Palazzo Valperga Galleani di Barbaresco a Torino. Torino: Editris.

Cornaglia P. (2003). Guida ai cortili di Torino. Torino: Anteprima.

Griseri A. (1995). Il Palazzo Saluzzo Paesana.Torino: Allemandi.

Hajian H., Becerik-Gerber B. (2010). Scan to BIM: Factor Affecting Operational and Computational Errors and Productivity Loss. In 27th International Symposium on Automation and Robotics in Construction, pp. 265-272. Los Angeles: ISARC.

Herráez Boquera J., Navarro Esteve P., Denia Ríos J. L. (20 I0). Fundamentos y aplicaciones de la tecnología de Escáner Láser para documentación y restauración del patrimonio. Algunos ejemplos de aplicación en La Comunidad Valenciana. In A. Alcántara Onofre, A. M. Lara Gutiérrez (a cura di). Implementación de nuevos métodos de documentación y registro fotogramétrico digital para la protección y puesta en valor del patrimonio monumental mexicano, pp. 17-4I. Ciudad de México: Universidad Politécnica de Valencia.

Magnaghi A. (1992). Torino: mappa concettuale della città antica ottenuta mediante mosaico delle piante degli edifici ricavate da diverse fonti iconografiche. In Atti e rassegna tecnica della Società degli ingegneri e degli architetti in Torino, XLVI (n. I0- I2).

Ogawa T., HoriY. (2019). Comparison with accuracy of terrestrial laser scanner by using point cloud aligned with shape matching and best fitting methods. In The International Archives of the Photogrammetry, Remote Sensing and Spatial Information Sciences, 8th Intl. Workshop 3D-ARCH 3D Virtual Reconstruction and Visualization of Complex Architectures, vol. XLII-2N9, Bergamo 6-8 February 2019, pp. 535-54I. Bergamo: ISPRS

Pedrini A. ( 1955). Portoni e porte maestre in Piemonte: secoli XVII e XVIII. Torino: Pozzo Salvati Gros Monti.

Politecnico di Torino, Istituto di Architettura Tecnica (1968). Forma urbana ed architettura nella Torino barocca: dalle premesse classiche alle conclusioni neoclassiche, 2 voll., 3 tomi, ricerca diretta da A. Cavallari Murat, Torino: UTET.

Politecnico di Torino, Dipartimento Casa-Città (1984). Beni culturali ambientali nel Comune di Torino. Torino: Società degli ingegneri e degli architetti in Torino.

Spallone R., Vitali M. (2017). Volte stellari e planteriane negli atri barocchi in Torino. Ariccia: Aracne.

\section{Authors}

Marco Vitali, Politecnico di Torino, marco.vitali@polito.it

Concepción López González, Universitat Politècnica de València, mlopezg@ega.upv.es

Giulia Bertola, Politecnico di Torino, giulia.bertola@polito.it

Fabrizio Natta, Politecnico di Torino, fabrizio.natta@polito.it

To cite this chapter:Vitali Marco, López González Concepción, Bertola Giulia, Natta Fabrizio (2021). Percorsi cerimoniali e organizzazione distributiva nei palazzi barocchi torinesi. Palazzo Capris di Ciglié/Ceremonial ways and distribution in the baroque palaces of Turin. Palazzo Capris di Ciglié. In Arena A., Arena M., Mediati D., Raffa P. (a cura di). Connettere. Un disegno per annodare e tessere. Linguaggi Distanze Tecnologie. Atti del $42^{\circ}$ Convono Internazionale dei Docenti delle Discipline dello Roppresentazione/Connecting Drawing for weaving relationship Languoges Distances Technologies. Proceedings of the $42^{\text {th }}$ International Conference of Representation Disciplines Teachers. Milano: FrancoAngeli, pp. I $274-1293$. 